\title{
Vascular plants affect properties and decomposition of moss-dominated peat, particularly at elevated temperatures
}

\author{
Lilli Zeh $^{1}$, Marie Theresa Igel ${ }^{1}$, Judith Schellekens ${ }^{2}$, Juul Limpens ${ }^{3}$, Luca Bragazza ${ }^{4}$, and Karsten Kalbitz ${ }^{1}$ \\ ${ }^{1}$ Soil Resources and Land Use, Institute of Soil Science and Site Ecology, Technische Universität Dresden, Pienner Str. 19, \\ 01737 Tharandt, Germany \\ ${ }^{2}$ Departamento de Ciência do Solo, Escola Superior de Agricultura “Luiz de Queiroz" - ESALQ/USP, Av. Pádua Dias 11, \\ Piracicaba, São Paulo, Brazil \\ ${ }^{3}$ Plant Ecology and Nature Conservation, Wageningen University, Droevendaalse steeg 3a, 6708 PB, \\ Wageningen, the Netherlands \\ ${ }^{4}$ Agroscope, Plant Production Systems, Route de Duillier 50, P.O. Box 1012, 1260 Nyon, Switzerland
}

Correspondence: Lilli Zeh (lilli.zeh@tu-dresden.de)

Received: 19 December 2019 - Discussion started: 16 January 2020

Revised: 4 August 2020 - Accepted: 13 August 2020 - Published: 5 October 2020

\begin{abstract}
Peatlands, storing significant amounts of carbon, are extremely vulnerable to climate change. The effects of climate change are projected to lead to a vegetation shift from Sphagnum mosses to sedges and shrubs. Impacts on the present moss-dominated peat remain largely unknown. In this study, we used a multiproxy approach to investigate the influence of contrasting vascular plant types (sedges, shrubs) on peat chemistry and decomposition. Peat cores of $20 \mathrm{~cm}$ depth and plant material (Sphagnum spp., Calluna vulgaris and Eriophorum vaginatum) from two ombrotrophic peatlands in the Italian Alps with a mean annual temperature difference of $1.4{ }^{\circ} \mathrm{C}$ were analyzed. Peat cores were taken under adjacent shrub and sedge plants growing at the same height above the water table. We used carbon, nitrogen and their stable isotopes to assess general patterns in the degree of decomposition across sampling locations and depths. In addition, analytical pyrolysis was applied to disentangle effects of vascular plants (sedge, shrub) on chemical properties and decomposition of the moss-dominated peat.

Pyrolysis data confirmed that Sphagnum moss dominated the present peat irrespective of depth. Nevertheless, vascular plants contributed to peat properties as revealed by, e.g., pyrolysis products of lignin. The degree of peat decomposition increased with depth as shown by, e.g., decreasing amounts of the pyrolysis product of sphagnum acid and increasing $\delta^{13} \mathrm{C}$ with depth. Multiple parameters also revealed a higher degree of decomposition of Sphagnum-dominated
\end{abstract}

peat collected under sedges than under shrubs, particularly at the high temperature site. Surprisingly, temperature effects on peat decomposition were less pronounced than those of sedges. Our results imply that vascular plants affect the decomposition of the existing peat formed by Sphagnum, particularly at elevated temperature. These results suggest that changes in plant functional types may have a stronger impact on the soil carbon feedback in a warmer world than hitherto assumed.

\section{Introduction}

Peatland soils store about $550 \mathrm{Gt}$ of carbon (C), which equals one-third of all soil organic $\mathrm{C}$, while they only cover $3 \%$ of the world's land area (Parish et al., 2008). In contrast to mineral soils, $\mathrm{C}$ sequestration in peatlands is not controlled by stabilization processes related to soil minerals (Schmidt et al., 2011) but is environmentally constrained by low temperatures and prevalent anoxic conditions (high water tables). Climate change is expected to partly lift these environmental constraints on microbial decomposition by warmer (Karhu et al., 2014) and drier conditions, threatening to release stored organic $\mathrm{C}$ as $\mathrm{CO}_{2}$ to the atmosphere. Alterations in the environment will also initiate shifts in vegetation composition, generally favoring vascular plants (sedge, shrub) over Sphagnum (moss) (Berendse et al., 2001; Breeuwer et al., 2009; 
Heijmans et al., 2008; Malmer et al., 1994). A systematic change in composition of plant functional types (PFTs) towards vascular plants has an as yet unknown potential to accelerate $\mathrm{C}$ losses from the stored peat originally dominated by mosses due to increased $\mathrm{C}$ input via roots from vascular plants (Bragazza et al., 2013; Gavazov et al., 2018; Robroek et al., 2015) and litter mixing effects (Zhang et al., 2019).

Vascular plants in alpine peatlands were shown to have up to twice as high net biomass production as mosses (Gerdol et al., 2010) and consequently relatively higher litter inputs than mosses. In addition to litter quantity, the chemical composition differs between PFTs with considerable consequences on decomposition dynamics. Sphagnum litter tends to decompose slower than vascular plant litter (Bragazza, 2006; Coulson and Butterfield, 1978; Verhoeven and Toth, 1995; Zhang et al., 2019) due to high carbon-to-nitrogen (C/N) ratio and decay-inhibiting structural carbohydrates (Coulson and Butterfield, 1978; Hájek et al., 2011; Schellekens et al., 2015b; Turetsky et al., 2008). Within vascular plants, shrub litter differentiates from sedge litter by higher $\mathrm{C} / \mathrm{N}$ ratio and lower decay rate (Huang et al., 1998; Kaštovská et al., 2018; Laiho et al., 2003; Limpens and Berendse, 2003). Analogous to biomass production, shrubs and sedges have higher belowground input of fresh root litter (Schellekens et al., 2011) and $\mathrm{C}$ input of living roots in comparison to mosses (i.e., fresh photosynthates; Zeh et al., 2019). Growth and reproduction of microorganisms are supposed to increase with higher root activity (Bragazza et al., 2015; Ward et al., 2013), which is likely to stimulate peat decomposition. Translating the PFT properties outlined above into consequences for $\mathrm{C}$ storage of autochthonous peats where inputs of all species are mixed together remains a challenge, particularly if the impact of recently changing vegetation on the previously formed peat is of interest. This challenge calls for a multiproxy approach (Biester et al., 2014) for determining the impact of the varying properties of PFTs on peat decomposition in situ.

Various analytical approaches exist to assess peat properties and decomposition, each with its own advantages and drawbacks. Carbon-to-nitrogen ratios have been widely used to evaluate decomposition of peat (Biester et al., 2014; Broder et al., 2012; Kuhry and Vitt, 1996; Limpens and Berendse, 2003; Taylor et al., 1989). The microbial mineralization of C-rich compounds and the subsequent respiration and emission as $\mathrm{CO}_{2}$ decreases the abundance of $\mathrm{C}$ relative to $\mathrm{N}$ (Broder et al., 2012). In combination with a high immobilization of $\mathrm{N}$ by microbial biomass, $\mathrm{N}$ will be further enriched in the remaining organic material (Damman, 1988). Consequently, $\mathrm{C} / \mathrm{N}$ ratios are decreasing with increasing decomposition. However, PFTs influence the $\mathrm{C} / \mathrm{N}$ ratio of peat too, as their litter differs in $\mathrm{C}$ and $\mathrm{N}$ contents (Hornibrook et al., 2000).

The stable isotopes ${ }^{13} \mathrm{C}$ and ${ }^{15} \mathrm{~N}$ and their vertical trends have been often used alongside $\mathrm{C} / \mathrm{N}$ ratios to reflect changes in decomposition (Biester et al., 2014; Broder et al., 2012; Coolen and Orsi, 2015; Krüger et al., 2014, 2015; Novák et al., 1999). Aerobic peat decomposition leads to an enrichment in $\delta^{13} \mathrm{C}$ and $\delta^{15} \mathrm{~N}$ due to a preferential use of the lighter isotopes by microorganisms and hence a relative enrichment of ${ }^{13} \mathrm{C}$ and ${ }^{15} \mathrm{~N}$ in the remaining organic matter (Alewell et al., 2011; Bragazza et al., 2010; Bragazza and Iacumin, 2009; Kalbitz et al., 2000; Nadelhoffer and Fry, 1988). However, stable isotope patterns are also affected by the water table limiting aerobic decomposition and thus isotopic discrimination in the remaining peat (Krüger et al., 2015) and the plant species forming the litter. Sedge leaves were found to be more enriched in ${ }^{13} \mathrm{C}$ and ${ }^{15} \mathrm{~N}$ than shrub leaves. The isotopic ratios for living plant parts found in this study are consistent with the ranges reported in previous studies. Sedge leaves were found to vary in $\delta^{13} \mathrm{C}$ signature between $-27.0 \%$ and $-26.85 \%$ and in $\delta^{15} \mathrm{~N}$ between $-3.96 \%$ and $-0.9 \%$; reported ranges for $\delta^{13} \mathrm{C}$ in shrub leaves are $-29.2 \%$ to $-28.83 \%$ and for $\delta^{15} \mathrm{~N}-10.92 \%$ o to $-9.7 \%$ o (Biester et al., 2014; Gavazov et al., 2016; Ménot and Burns, 2001; Nordbakken et al., 2003). Sphagnum samples were found to vary in $\delta^{13} \mathrm{C}$ signature between $-30.4 \%$ and $-25.0 \%$ (Bragazza and Iacumin, 2009; Loisel et al., 2009; Preis et al., 2018; Price et al., 1997; Proctor et al., 1992) and in $\delta^{15} \mathrm{~N}$ signatures between $-7.5 \%$ and $2.5 \%$ (Asada et al., 2005; Biester et al., 2014; Bragazza et al., 2005; Kohzu et al., 2003; Ménot and Burns, 2001; Nordbakken et al., 2003).

Pyrolysis-gas chromatography/mass spectrometry (pyGC/MS) is a powerful but labor-intensive tool to characterize the composition of peat and disentangle the effects of source material from decomposition (Abbott et al., 2013; Huang et al., 1998; McClymont et al., 2011; Schellekens et al., 2012, 2015a, b). Plant-specific pyrolysis products which have been used to distinguish vascular plants from Sphagnum in peat include lignin phenols from lignin and 4-isopropenylphenol from sphagnum acid, respectively (Van Der Heijden et al., 1997; McClymont et al., 2011; Schellekens et al., 2009, 2015b, c).

In this multiproxy study, we combined the analytical approaches outlined above to explore the influence of vascular plants on chemical properties and degree of peat decomposition in two moss-dominated peatlands contrasting in temperature. We hypothesized that (i) chemical properties of the moss-dominated peat differ under shrub and sedge coverage, (ii) the decomposition of the moss-dominated peat increases with depth and is higher under sedge than shrub coverage, and (iii) increasing temperature is reflected in a higher degree of decomposition of the moss-dominated peat, particularly under sedge coverage.

\section{Material and methods}

\subsection{Study sites}

Two ombrotrophic peatlands at different altitude in the northeastern Alps of Italy were chosen to simulate a climate warm- 
ing scenario. The peatland at lower altitude, Lupicino, is located at $1290 \mathrm{~m}$ a.s.l. and is characterized by a mean annual temperature (MAT) of $6.3^{\circ} \mathrm{C}$ and a total annual precipitation of $810 \mathrm{~mm}$. The peatland at higher altitude, Palù Tremole, is located at $1700 \mathrm{~m}$ a.s.l. with a MAT of $4.9^{\circ} \mathrm{C}$ and total annual precipitation of $825 \mathrm{~mm}$. Soil temperature in $10 \mathrm{~cm}$ depth between August 2015 and July 2016 was $7.1^{\circ} \mathrm{C}$ at Lupicino and $5.9^{\circ} \mathrm{C}$ at Palù Tremole. Lupicino will be referred to as the high-temperature (high $T$ ) site and Palù Tremole as the low-temperature (low $T$ ) site. The time during which the top $20 \mathrm{~cm}$ of the peat was above the water table was determined with water table measurements between August 2015 and July 2016 at three gauges on each site. At the low $T$ site, the water table remained below $20 \mathrm{~cm}$ for 137,138 and $284 \mathrm{~d}$ of the year; at the high $T$ site, this was 117,360 and $366 \mathrm{~d}$ of the year respectively. Furthermore, in peatlands with similar vegetation cover, situated at 1030 and $1880 \mathrm{~m}$ a.s.l. in Switzerland, the age of peat in 15-20 depth was found to be 40 and 26 years, respectively (Gavazov et al., 2018), meaning that the potential age difference between the peat sampled at our sites is likely less than 15 years. The vegetation community on both sites is similar and dominated by Sphagnum spp., with contributions from Calluna vulgaris and Eriophorum vaginatum, representing the three PFTs (bryophyte mosses, ericoid shrubs, graminoid sedges). This experimental setup offers a unique opportunity to disentangle impacts of shrubs and sedges on properties and decomposition of a moss-dominated peat. Further detail in biotic and climatic conditions can be found in Zeh et al. (2019).

\subsection{Sampling and preparation}

During the first half of August 2015, we selected 20 hummocks per study site with a closed peat moss cover of at least $95 \%$, an equal proportion of shrub-to-sedge cover and a total vascular plant cover of $47 \pm 2 \%$ at the low $T$ site and $77 \pm 2 \%$ at the high $T$ site. The hummocks were located in five groups (blocks) of four hummocks, with maximally $5 \mathrm{~m}$ between the hummocks within a block. On each hummock, we took two peat cores: one directly under $C$. vulgaris (shrub core) and one under E. vaginatum tussocks (sedge core), yielding a total of 40 cores per peatland. Peat was defined as all organic bulk material accumulating underneath the peatland surface, comprised of a matrix of mostly dead Sphagnum material with embedded living and dead stems and roots of $C$. vulgaris and E. vaginatum. Peat cores were sampled with a custom-made metal peat corer with an inside diameter of $5 \mathrm{~cm}$ and a sampling length of $20 \mathrm{~cm}$. Additionally, photosynthetically active moss tissues from the top $2 \mathrm{~cm}$ and plant shoots from $E$. vaginatum and $C$. vulgaris were collected from each hummock. Furthermore, six separate peat cores with $10 \mathrm{~cm}$ diameter (three at each site) were randomly sampled for collection of living roots of shrubs and sedges. During the field campaign, peat cores were stored at $8^{\circ} \mathrm{C}$ within PVC tubes to prevent deformation. Afterwards, they were frozen to $-20^{\circ} \mathrm{C}$ until further sample preparation.

Of the collected 80 peat cores, the 20 most representative cores were selected using three criteria: (i) peat cores with a minimum length of $20 \mathrm{~cm}$ and without physical damages, (ii) one shrub core and one sedge core from each block and peatland, and (iii) peat cores with the smallest deviation from the mean weight of the respective block. From the active moss tissues, samples were selected corresponding to the chosen peat cores and mixed, if not sampled from the same hummock.

To assess which depth increments are appropriate to characterize changes in peat properties, four cores (one sedge and one shrub from each site) were randomly chosen from the selected 20. These cores were cut into depth increments of $1 \mathrm{~cm}$, except for the topmost increment, which accounted for $2 \mathrm{~cm}$. Carbon and $\mathrm{N}$ concentrations were measured as described in Sect. 2.3. The results of these analyses indicated changes in $\mathrm{C}$ and $\mathrm{N}$ concentrations at 2,5 and $12 \mathrm{~cm}$. Considering these results, the remaining 16 peat cores were cut into four depth increments: 0-2, 2-5, 5-12 and 12-20 cm.

Plant and peat material was freeze-dried and then ground (Fritsch pulverisette 23) before being analyzed.

\subsection{Total carbon and nitrogen concentration and stable isotope analysis $\left({ }^{13} \mathrm{C},{ }^{15} \mathrm{~N}\right)$}

Carbon and $\mathrm{N}$ concentration were measured with a vario EL III elemental analyzer (Elementar Analysensysteme $\mathrm{GmbH}$, Langenselbold, Germany), following standard processing techniques. Carbon and $\mathrm{N}$ concentrations were calculated based on total sample weight. The $\mathrm{C} / \mathrm{N}$ ratio represents the atomic relationship between $\mathrm{C}$ and $\mathrm{N}$ content of the peat material.

Isotope analysis was done with the vario PYRO cube coupled to the visION IRMS (Isoprime, Elementar Analysensysteme $\mathrm{GmbH}$, Langenselbold, Germany). Stable C isotope ratios are reported as $\delta^{13} \mathrm{C}$ in $(\% \circ)$ relative to the $\mathrm{V}-\mathrm{PDB}$ standard and stable $\mathrm{N}$ isotope ratios as $\delta^{15} \mathrm{~N}$ in (\%o) relative to air.

\subsection{Pyrolysis-gas chromatography/mass spectrometry}

To identify chemical properties of PFTs, peat and peat decomposition, representative plant samples for each PFT and one shrub core and one sedge core from each peatland were selected to be additionally analyzed by py-GC/MS. We defined peat decomposition as any changes in properties of the bulk peat relative to its source material, e.g., plant material from C. vulgaris, E. vaginatum and Sphagnum spp. directly after deposition.

Plant samples comprised of one root and one shoot sample of shrub and sedge, respectively, and one moss tissue sample from each peatland. In total 10 plant samples and four cores were cut into four increments as previously described. They were chosen based on the lowest deviation from the 
mean in $\mathrm{C} / \mathrm{N}, \delta^{13} \mathrm{C}$ and $\delta^{15} \mathrm{~N}$ analyses. A pyrolyzer EGA/PY3030D device (Frontier Laboratories, Fukushima, Japan) has been used for analysis. The pyrolysis temperature was set at $600^{\circ} \mathrm{C}$ and held for $10 \mathrm{~s}$. The pyrolyzer was connected with a GC 7890B and MS 5977 (Agilent Technologies, Santa Clara, United States). Inlet temperature of the $\mathrm{GC}$ was $250^{\circ} \mathrm{C}$ (split $50: 1$ ). The $\mathrm{GC}$ oven had an initial temperature of $45^{\circ} \mathrm{C}$ (held for $4 \mathrm{~min}$ ), was then heated to $240^{\circ} \mathrm{C}$ at $4^{\circ} \mathrm{C} \mathrm{min}^{-1}$, and was heated afterwards to $300^{\circ} \mathrm{C}$ at $39^{\circ} \mathrm{C} \mathrm{min}^{-1}$ (held for $15 \mathrm{~min}$ ). The GC column, a ZB-5ms (Zebron, Phenomenex Inc., Torrance, United States), had a length of $30 \mathrm{~m}$, a film thickness $0.25 \mu \mathrm{m}$ and a diameter of $0.25 \mathrm{~mm}$. The MS was scanning in the range of $m / z, 50-600$.

Pyrolysis product identification and peak integration in pyrograms were performed with Masslab. Based on intensity and frequency on the total ion current (TIC), 57 pyrolysis products were selected for quantification in all 26 samples (A1). Quantification was based on the peak area of characteristic fragment ions $(m / z)$ for each product (A1). The relative proportion of each product was expressed as a percentage of the total quantified peak area in one sample (TIC: 100\%). The products were grouped according to chemical similarity and their source into $n$-alkenes and $n$-alkanes, lignin-derived products, phenols, benzenes, and polysaccharides.

\subsection{Selection of molecular parameters}

Based on the results of previous pyrolysis studies from peatlands, a number of pyrolytic parameters reflecting plant species and the degree of peat decomposition were extracted (Table 1). A pyrolysis product specific for sphagnum acid (4isopropenylphenol; Van Der Heijden et al., 1997) has been found to very sensitively reflect aerobic decomposition of Sphagnum tissue in Sphagnum-dominated peat (Schellekens et al., 2015b). Methoxyphenols are unique to lignin, thereby providing a measure for the contribution from vascular plants in peat dominated by Sphagnum, because Sphagnum contains no lignin (Abbott et al., 2013; Kracht and Gleixner, 2000; Schellekens et al., 2015c; van Smeerdijk and Boon, 1987). Since both shrubs and sedges contain lignin, additional parameters were included to distinguish between them. Sedges have large contributions from $p$-coumaric and ferulic acid (Lu and Ralph, 1999) with typical pyrolysis products 4-vinylphenol ( $\operatorname{Lg} 1)$ and 4-vinylguaiacol $(\operatorname{Lg} 4)$, respectively (Van Der Hage et al., 1993). Because 4-vinylphenol is also abundant in Sphagnum tissue (van Smeerdijk and Boon, 1987), the ratio of 4-vinylguaiacol to the summed guaiacyl products $(\mathrm{G})$ can therefore be used to reflect sedges (Schellekens et al., 2012). The ratio of $\mathrm{C}_{3}$-guaiacol to $\mathrm{G}$ usually reflects intact lignin in soils but has been found to be indicative of shrubs in peat (Schellekens et al., 2012, 2015a). $n$ Alkenes and $n$-alkanes (Al) originate from cutan and suberan present in roots and bark (Nierop, 1998; Tegelaar et al., 1995) as well as leaf waxes (Eglinton and Hamilton, 1967), depending on their chain length, all of which are associated with shrubs in Sphagnum-dominated peat (Schellekens and Buurman, 2011; van Smeerdijk and Boon, 1987).

\subsection{Statistics}

All data analysis and visualization were performed with R, version 3.6 ( $\mathrm{R}$ Core Team, 2019). The preliminary four peat cores which were cut into $1 \mathrm{~cm}$ increments were integrated in the statistical analysis. For this purpose, the means of $\mathrm{C}(\%)$, $\mathrm{N}(\%), \mathrm{C} / \mathrm{N}$ ratio, $\delta^{13} \mathrm{C}(\% o)$ and $\delta^{15} \mathrm{~N}(\% \circ)$ were calculated for each depth increment $(2-5,5-12$ and $12-20 \mathrm{~cm})$. Linear mixed-effect models (LMMs) were applied to results of the $\mathrm{C} / \mathrm{N}$ ratio, $\delta^{13} \mathrm{C}$ and $\delta^{15} \mathrm{~N}$ analysis to consider the nested structure of peat cores in blocks using package "Ime4" (Bates et al., 2015). Vascular plant effect (shrub vs. sedge), site (low $T$ vs. high $T$ ) and depth increments were analyzed as fixed effect factors, whereby the peat cores nested in blocks were accounted for as a random factor with random intercept structure. If the assumptions of normality in the data and their residuals were met (checked with the Shapiro-Wilk test, histograms and Q-Q plots), a subsequent analysis of variance type II with a Kenward-Roger approximation of degree of freedom was applied on the linear mixed models for hypothesis testing using package "ImerTest" (Kuznetsova et al., 2017). A post hoc test was accomplished with a pairwise Tukey test applying package "emmeans" (Lenth, 2019). Since data and residuals of the $\mathrm{C} / \mathrm{N}$ ratio, $\delta^{13} \mathrm{C}$ and $\delta^{15} \mathrm{~N}$ in shoot materials were not normally distributed, single effects were tested with Wilcoxon test. Due to limited root sample size, hypothesis tests were neglected.

Principal component analysis (PCA) was applied to the py-GC/MS data. The aim was to reduce the data to a set of uncorrelated, meaningful components. Each principal component is determined by the largest variance (or largest remaining variance) of all quantified pyrolysis products and therefore explains a specific percentage of the total variance. They may represent a single effect on peat chemistry, while the abundance of individual pyrolysis products (or other variables) may be influenced by several environmental factors. Scores indicate to which extent each principal component contributes to a sample. Loadings demonstrate which individual pyrolysis products are responsible for the patterns in scores. Prior to PCA, the number of pyrolysis products (variables) was adapted. First, the $n$-alkenes and $n$-alkanes were pooled to a single variable since these products were large in number (10 and 9 , respectively) but in sum only contributed less than $1 \%$ to total abundance. The allocation of this large set of correlated variables with small abundance to the first principal component was avoided (Schellekens et al., 2017). Second, key molecular parameters (Sect. 2.5, Table 1) were included as variables to check their interpretation within the studied plant samples and peat cores. This resulted in a total number of 41 variables for PCA. To unravel the effects of vascular plants and temperature on peat decomposition in de- 
Table 1. Overview of all parameters used in this study to determine impacts of plant functional types (PFTs) on peat properties and decomposition of the moss-dominated peat (for abbreviations of the parameter see legend of Fig. 3).

\begin{tabular}{|c|c|c|c|}
\hline Parameter & Unit & Indication & Interpretation in Sphagnum-dominated peat \\
\hline $\mathrm{C} / \mathrm{N}$ & - & $\begin{array}{l}\text { preferential decomposition of } \\
\text { C over } \mathrm{N}\end{array}$ & aerobic decomposition \\
\hline$\delta^{13} \mathrm{C}$ & $(\% \circ)$ & $\begin{array}{l}\text { preferential decomposition of } \\
{ }^{12} \mathrm{C} \text { over }{ }^{13} \mathrm{C} \text { isotope }\end{array}$ & aerobic decomposition \\
\hline$\delta^{15} \mathrm{~N}$ & $(\% \circ)$ & $\begin{array}{l}\text { preferential decomposition of } \\
{ }^{14} \mathrm{~N} \text { over }{ }^{15} \mathrm{~N} \text { isotope }\end{array}$ & aerobic decomposition \\
\hline $\begin{array}{l}\text { sum of } \mathrm{G} \text { and } \mathrm{S} \\
\text { lignin products }\end{array}$ & $\left(\% \mathrm{TIC}^{\mathrm{a}}\right)$ & lignin & vascular plants (van Smeerdijk and Boon, 1987) \\
\hline $\begin{array}{l}\text { sum of } n \text {-alkenes } \\
\text { and } n \text {-alkanes }\end{array}$ & $\left(\% \mathrm{TIC}^{\mathrm{a}}\right)$ & cutan, suberan, leaf waxes & $\begin{array}{l}\text { ericoid shrubs (Schellekens and Buurman, 2011; } \\
\text { van Smeerdijk and Boon, 1987) }\end{array}$ \\
\hline $\mathrm{C}_{3} \mathrm{G} / \mathrm{G}$ & - & intact lignin & ericoid shrubs (Schellekens et al., 2012) \\
\hline 4-vG/G & - & ferulic acid & $\begin{array}{l}\text { sedges (van Smeerdijk and Boon, 1987; Schellekens et al., } \\
\text { 2012) }\end{array}$ \\
\hline $\begin{array}{l}\text { 4-isopropenylphenol } \\
\text { (Ph6) }\end{array}$ & $\left(\% \mathrm{TIC}^{\mathrm{a}}\right)$ & sphagnum acid & $\begin{array}{l}\text { aerobic decomposition of Sphagnum tissues (preferential } \\
\text { loss of polyphenols over polysaccharides; Schellekens et } \\
\text { al., 2015b) }\end{array}$ \\
\hline $\begin{array}{l}\text { levoglucosan/sum of } \\
\text { polysaccharides }\end{array}$ & - & cellulose & $\begin{array}{l}\text { aerobic decomposition of Sphagnum tissues (preservation } \\
\text { of Sphagnum polysaccharides; Schellekens et al., 2015b) }\end{array}$ \\
\hline
\end{tabular}

${ }^{\mathrm{a}}$ Total ion current. ${ }^{\mathrm{b}}$ Interpretation refers to relatively low values.

tail, the regression analysis and depth records of these molecular parameters are discussed (Sect. 4.1.2, 4.2).

\section{Results}

\subsection{Carbon-to-nitrogen ratios and isotopic composition of PFTs and peat}

Carbon-to-nitrogen ratios and isotopic composition of plant shoots were different between plant tissues, PFTs and to a lesser extent between sites (Fig. 1). Living plant shoots had consistently lower $\mathrm{C} / \mathrm{N}$ ratios than plant roots irrespective of site or PFT (Fig. 1a). Sedge shoots had significantly lower $\mathrm{C} / \mathrm{N}$ ratios ( $p<0.001$, Fig. 1a) and were significantly enriched in ${ }^{13} \mathrm{C}(p<0.001$, Fig. 1b) compared to moss and shrub shoots. Shrub shoots were significantly depleted in $\delta^{15} \mathrm{~N}$ compared to sedge and moss shoots $(p<0.001$, Fig. 1c). Sedge shoots and moss from the high $T$ site were both significantly depleted in ${ }^{13} \mathrm{C}$ compared to the low $T$ site (both $p<0.01$, Fig. 1b).

Peat $\mathrm{C} / \mathrm{N}$ ratio and isotopic composition was significantly affected by depth, site and to a lesser extent by PFTs (Fig. 2a, b). The $\mathrm{C} / \mathrm{N}$ ratio increased with depth and was higher at the high $T$ site compared to the low $T$ site (Fig. 2a, Table 2). In the upper $0-2 \mathrm{~cm}$ peat layer, $\mathrm{C} / \mathrm{N}$ ratios and stable isotopes corresponded with values observed for moss (Figs. 1,
$2)$. The isotopic composition of peat increments was significantly different for depths and PFTs (Table 2). $\delta^{13} \mathrm{C}$ and $\delta^{15} \mathrm{~N}$ of peat increased with depth (Fig. 2b, c), and the enrichment in ${ }^{13} \mathrm{C}$ with depth was stronger for sedge cores than for shrub cores (i.e., $2.7 \pm 0.4 \%$ o for sedge cores and $1.6 \pm 0.4 \%$ o for shrub cores). The largest enrichment in $\delta^{13} \mathrm{C}$ between the uppermost and lowest depth increment appeared in sedge cores at the high $T$ site (Fig. 2b; i.e., $3.5 \pm 0.5 \%$ ).

\subsection{Chemical composition of vascular plants and moss-dominated peat analyzed by py-GC/MS}

Groups of pyrolysis products are given in Table 3. In the peat samples, polysaccharides (Ps) contributed 56\%-86\% and phenols (Ph) 7\%-30\% to all identified pyrolysis products, while the contribution from lignin-derived products ( $\mathrm{Lg}$ ) was $<15 \%$. The PCA (Fig. 3) clearly showed differences in the chemical composition of the PFT tissues and peat.

Principal components (PC) 1 to 3 explained $75.6 \%$ and hence the major part of the variance in py-GC/MS data. Plotting the scores of PC1 versus PC2 (Fig. 3a) revealed that plant materials of the PFTs as well as peat from different depths clustered based on their pyrolysis products and thus on chemical composition. PC1 separated both shoot and root samples of shrubs and sedges with exclusively positive scores from moss samples with exclusively negative scores. 

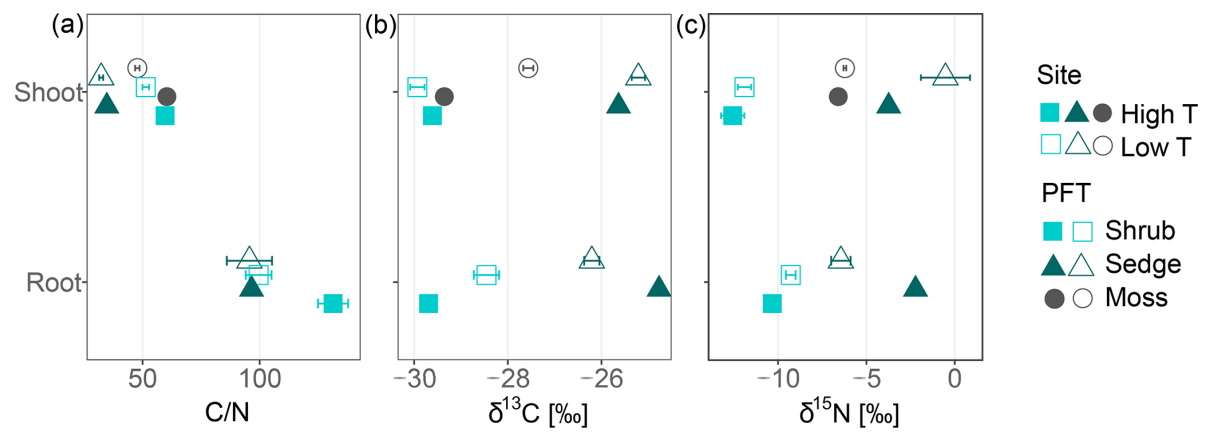

Figure 1. Carbon-to-nitrogen $(\mathrm{C} / \mathrm{N})$ ratios, $\delta^{15} \mathrm{~N}(\% \circ)$ and $\delta^{13} \mathrm{C}(\%)$ of shoot and root tissues from three plant functional types (PFTs; i.e., mosses, shrubs and sedges) and from two peatlands differing in temperature (high and low temperature indicated by high $T$ and low $T$, respectively). Symbols for shoots represent mean values with standard error $(n=5)$, whereas symbols for roots give means of two or a single value (high $T$ sedge root).
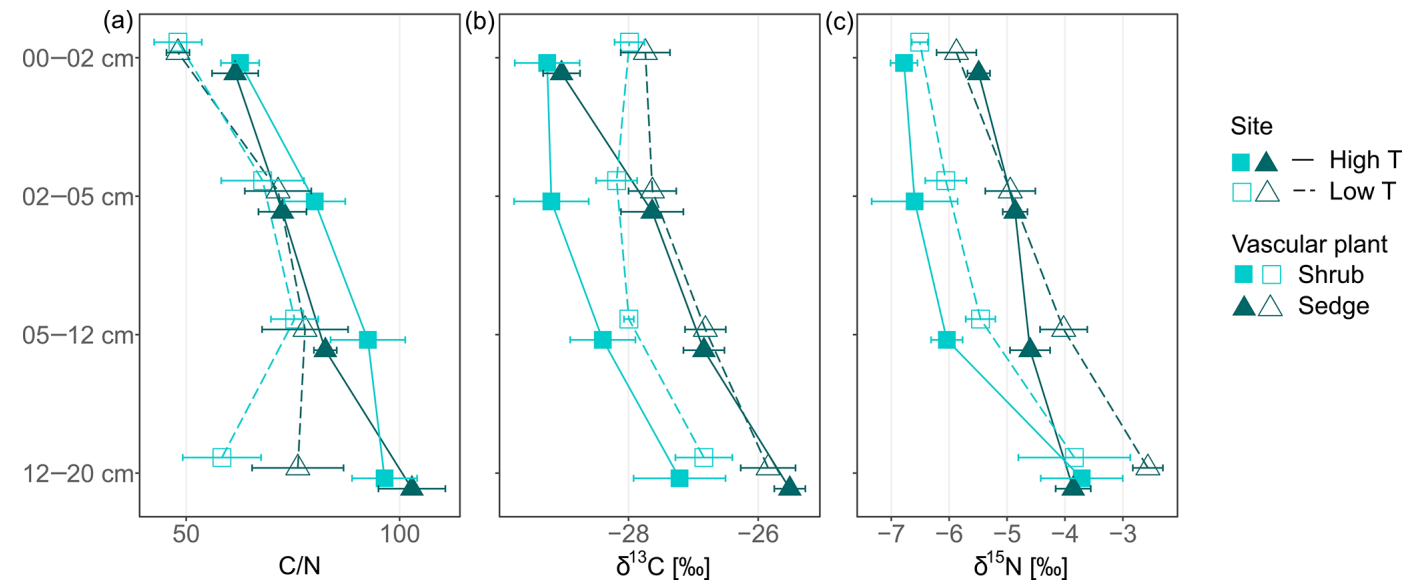

Vascular plant

$\square$ Shrub

$\triangle$ Sedge

Figure 2. Carbon-to-nitrogen $(\mathrm{C} / \mathrm{N})$ ratios, $\delta^{15} \mathrm{~N}(\% \circ)$ and $\delta^{13} \mathrm{C}(\% \circ)$ of peat core increments from two peatlands differing in temperature (high and low temperature indicated by high $T$ and low $T$, respectively) and covered by two different vascular plants (shrub and sedge). Symbols represent mean values with standard error $(n=5)$.

Thus, PC1 distinguished vascular plant samples from moss samples. Peat samples were arranged in between, reflecting the contribution of both vascular plants and mosses. The pyrolysis products responsible for the separation of PFTs are reflected in the factor loadings. Most phenols, including the parameter for sphagnum acid (4-isopropenylphenol, $\mathrm{Ph} 6$ ), and some polysaccharides (Ps1, 2, 4, 8, 9) had negative loadings on PC1, corresponding to moss samples (Fig. 3b). Ligninderived products (sum of guaiacyl and syringyl lignin products, GS) had positive loadings and are indicative of shoot and root tissues of vascular plants (Fig. 3b).

Scores of PC2 separate aboveground shoot tissues of the three PFTs and the surface peat (negative scores) from root tissues and the deeper peat increments (positive scores; Fig. 3a); within the peat samples, the deepest increments had the highest positive scores. Levoglucosan (Ps16) and the ratio of levoglucosan to the sum of polysaccharides (L/Ps) had the largest positive loadings, which indicate its relative enrichment with depth.
PC3 separates samples based on the two vascular plants, i.e., shrubs and sedges (Fig. 3c). Shrub shoot and root samples had exclusively negative scores. In contrast, all sedge shoot and root samples had positive scores. The peat samples clustered in between (i.e., low scores) but maintained the separation according to vascular plants. Likewise, the parameters selected to reflect the contribution from shrub, i.e., sum of $n$-alkenes and $n$-alkanes (Al, Table 1 ) and the ratio of $\mathrm{C}_{3}$ guaiacol to the sum of guaiacyl products $\left(\mathrm{C}_{3} \mathrm{G} / \mathrm{G}\right.$, Table 1$)$, had high negative loading on PC3. The parameter for sedge (the ratio of 4-vinylguaiacol to the sum of guaiacyl products (4VG/G), Table 1) showed positive loading on PC3 (Fig. 3b). The loadings furthermore suggest that both benzenes and levomannosan (Ps15) were associated with shrub as well, while 2,3-dihydro-5-methylfuran-2-one (Ps3) and guaiacol ( Lg2) showed high positive loading and are thus indicative of sedge in this context. 
Table 2. Type II analysis of variance with Kenward-Roger's approximation of degrees of freedom applied on carbon-to-nitrogen (C/N) ratios, $\delta^{13} \mathrm{C}$ and $\delta^{15} \mathrm{~N}$ of peat cores $(n=5)$. Numbers in bold indicate significant values $(p<0.05)$.

\begin{tabular}{lrrr|rrr|rrrr}
\hline & \multicolumn{4}{c|}{$\mathrm{C} / \mathrm{N}$} & \multicolumn{3}{|c|}{$\delta^{13} \mathrm{C}$} & \multicolumn{3}{|c}{$\delta^{15} \mathrm{~N}$} \\
\cline { 2 - 10 } & DF & $F$ test & $p$ & DF & $F$ test & $p$ & DF & $F$ test & $p$ \\
\hline Vascular plants (VP) & 1 & 0.15 & 0.69 & 1 & 27.05 & $<\mathbf{0 . 0 0 1}$ & 1 & 25.79 & $<\mathbf{0 . 0 0 1}$ \\
Site & 1 & 19.04 & $\mathbf{0 . 0 0 2}$ & 1 & 3.17 & 0.11 & 1 & 1.62 & 0.24 \\
Depth & 3 & 12.75 & $<\mathbf{0 . 0 0 1}$ & 3 & 24.21 & $<\mathbf{0 . 0 0 1}$ & 3 & 28.46 & $<\mathbf{0 . 0 0 1}$ \\
VP $\times$ site & 1 & 1.51 & 0.22 & 1 & 1.80 & 0.18 & 1 & 0.01 & 0.94 \\
VP $\times$ depth & 3 & 0.97 & 0.41 & 3 & 1.90 & 0.13 & 3 & 0.94 & 0.43 \\
Site $\times$ depth & 3 & 2.40 & 0.07 & 3 & 2.07 & 0.11 & 3 & 0.51 & 0.68 \\
Site $\times$ depth $\times$ VP & 3 & 0.12 & 0.94 & 3 & 0.32 & 0.81 & 3 & 1.26 & 0.29 \\
\hline
\end{tabular}

(a)

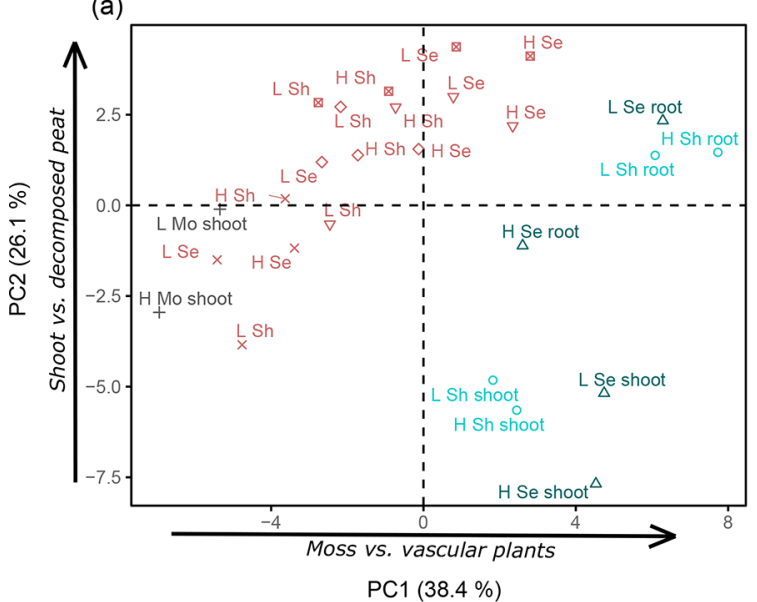

(c)

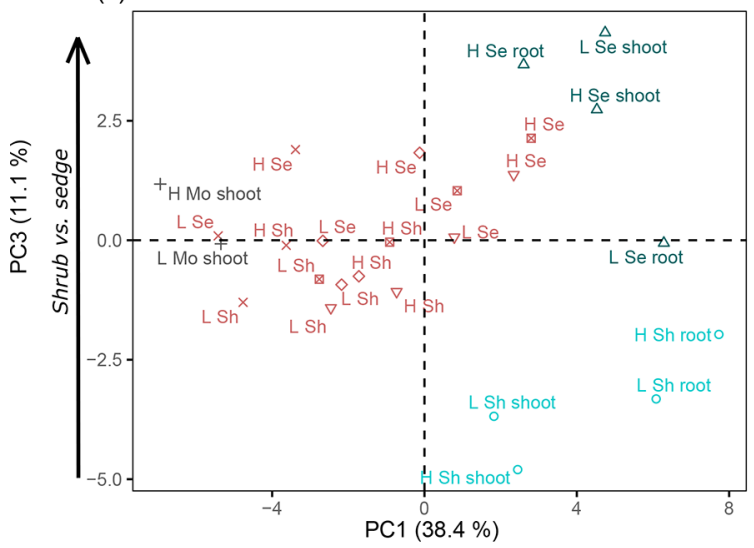

(b)

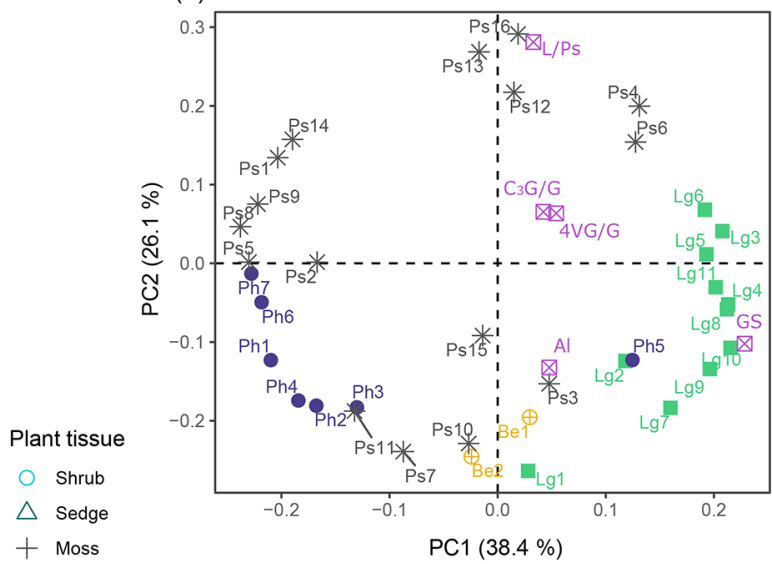

Compounds

$\oplus \mathrm{Be}$

$\otimes$ Group or ratio

Peat

× 00-02

(d)

$\diamond$ 02-05

$\nabla \quad 05-12$

\ 12-20

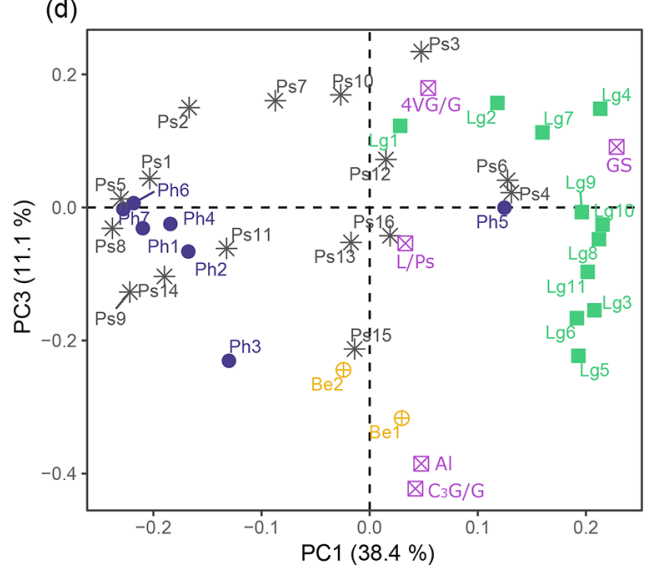

- $\mathrm{Lg}$

- $\mathrm{Ph}$

* Ps

Figure 3. Results of the principal component analysis (PCA) of the pyrolysis data to reveal molecular composition of peat and peat-forming plants. PC1 to PC2 projections of scores (a) and loadings (b), and PC1 to PC3 projections of scores (c) and loadings (d). Plant samples are labeled by site (H: high temperature; L: low temperature) and plant tissue (shoot, root). Peat samples are named by site and vascular plants (Se: sedge peat; Sh: shrub peat). The four depth increments are distinguished by symbols. Pyrolysis products correspond to codes that are given in (A1). Abbreviations are according to chemical group: benzenes (Be), lignin products (Lg), phenols ( $\mathrm{Ph}$ ) and carbohydrates (Ps). Additional variables are included in PCA, namely summed $n$-alkenes and $n$-alkanes (Al), 4-vinylguaiacol to the summed guaiacyl products (4VG/G), $C_{3}$-guaiacol to the summed guaiacyl products $\left(\mathrm{C}_{3} \mathrm{G} / \mathrm{G}\right)$, sum of guaiacyl and syringyl lignin products $(\mathrm{GS})$, and levoglucosan to summed polysaccharides (L/Ps). 
Table 3. Groups of all identified pyrolysis products for all samples: $n$-alkenes and $n$-alkanes (Al), benzenes (Be), lignin products (Lg), phenols $(\mathrm{Ph})$ and polysaccharides (Ps). The contribution of the single products in groups to total ion current were cumulated for each of the respective groups.

\begin{tabular}{|c|c|c|c|c|c|c|c|}
\hline Sample & PFT & Site & $\mathrm{Al}$ & $\mathrm{Be}$ & $\mathrm{Lg}$ & $\mathrm{Ph}$ & Ps \\
\hline \multicolumn{8}{|c|}{ Plant tissue } \\
\hline Shoot & Sedge & Low $T$ & 0.78 & 2.31 & 46.57 & 7.63 & 42.70 \\
\hline Shoot & Sedge & High $T$ & 1.11 & 4.87 & 48.89 & 15.42 & 29.71 \\
\hline Shoot & Shrub & Low $T$ & 3.98 & 6.63 & 26.40 & 21.87 & 41.12 \\
\hline Shoot & Shrub & High $T$ & 5.41 & 8.72 & 30.09 & 19.15 & 36.63 \\
\hline Shoot & Moss & Low $T$ & 1.13 & 2.83 & 6.25 & 25.37 & 64.42 \\
\hline Shoot & Moss & High $T$ & 1.02 & 3.37 & 8.76 & 33.39 & 53.46 \\
\hline Root & Sedge & Low $T$ & 0.77 & 1.85 & 32.23 & 5.50 & 59.65 \\
\hline Root & Sedge & High $T$ & 0.85 & 1.28 & 26.57 & 14.09 & 57.21 \\
\hline Root & Shrub & Low $T$ & 3.53 & 3.26 & 23.42 & 8.90 & 60.89 \\
\hline Root & Shrub & High $T$ & 2.19 & 1.97 & 24.71 & 7.35 & 63.78 \\
\hline \multicolumn{8}{|l|}{ Peat } \\
\hline $00-02 \mathrm{~cm}$ & Sedge & Low $T$ & 1.25 & 3.49 & 9.18 & 30.18 & 55.89 \\
\hline $00-02 \mathrm{~cm}$ & Sedge & High $T$ & 0.73 & 2.63 & 14.98 & 24.04 & 57.62 \\
\hline $00-02 \mathrm{~cm}$ & Shrub & Low $T$ & 2.52 & 5.64 & 13.65 & 29.06 & 49.13 \\
\hline $00-02 \mathrm{~cm}$ & Shrub & High $T$ & 1.44 & 2.86 & 8.77 & 22.03 & 64.90 \\
\hline $02-05 \mathrm{~cm}$ & Sedge & Low $T$ & 1.25 & 2.28 & 8.99 & 17.46 & 70.02 \\
\hline $02-05 \mathrm{~cm}$ & Sedge & High $T$ & 0.91 & 1.89 & 18.10 & 12.46 & 66.65 \\
\hline $02-05 \mathrm{~cm}$ & Shrub & Low $T$ & 1.04 & 1.94 & 4.60 & 10.03 & 82.39 \\
\hline $02-05 \mathrm{~cm}$ & Shrub & High $T$ & 1.68 & 2.31 & 9.45 & 16.86 & 69.70 \\
\hline $05-12 \mathrm{~cm}$ & Sedge & High $T$ & 1.05 & 1.63 & 21.69 & 8.11 & 67.52 \\
\hline $05-12 \mathrm{~cm}$ & Sedge & Low $T$ & 1.37 & 2.00 & 12.27 & 8.03 & 76.33 \\
\hline $05-12 \mathrm{~cm}$ & Shrub & Low $T$ & 2.35 & 3.07 & 12.72 & 20.62 & 61.24 \\
\hline $05-12 \mathrm{~cm}$ & Shrub & High $T$ & 1.36 & 2.34 & 7.87 & 12.51 & 75.91 \\
\hline $12-20 \mathrm{~cm}$ & Sedge & Low $T$ & 0.73 & 1.15 & 11.31 & 7.35 & 79.46 \\
\hline $12-20 \mathrm{~cm}$ & Sedge & High $T$ & 0.48 & 0.85 & 20.23 & 6.52 & 71.92 \\
\hline $12-20 \mathrm{~cm}$ & Shrub & Low $T$ & 0.95 & 1.59 & 2.65 & 8.28 & 86.53 \\
\hline $12-20 \mathrm{~cm}$ & Shrub & High $T$ & 0.99 & 1.54 & 8.19 & 9.70 & 79.58 \\
\hline
\end{tabular}

\section{Discussion}

\subsection{Properties of moss-dominated peat influenced by vascular plants}

Testing our hypotheses requires the identification of properties being typical of the different vascular plants. In our study, we were able to apply a set of properties with a different degree of specificity to reveal how shrubs and sedges affect chemical properties of moss-dominated peat.

\subsubsection{Different chemical properties of plant materials}

Properties such as $\mathrm{C} / \mathrm{N}$ ratios, $\delta^{13} \mathrm{C}$ and $\delta^{15} \mathrm{~N}$ of living plant parts showed significant differences between different PFTs (Fig. 1). $\mathrm{C} / \mathrm{N}$ ratios of sedge shoots were significantly lower than those of shrubs or mosses, which is in line with its higher decomposability (Kaštovská et al., 2018; Limpens and Berendse, 2003). The ${ }^{13} \mathrm{C}$ signature of plant tissue tends to be depleted under warmer and drier conditions (Broder et al., 2012; Gavazov et al., 2016; Skrzypek et al., 2007) explaining the observed $\delta^{13} \mathrm{C}$ depletion of sedge and moss tissues at the high $T$ site compared to the low $T$ site. Shrub shoots were significantly depleted in $\delta^{15} \mathrm{~N}$ compared to sedge and moss shoots ( $p<0.001$, Fig. 1c). The depletion of $\delta^{15} \mathrm{~N}$ in living $C$. vulgaris shoots compared to shoots of $E$. vaginatum and Sphagnum spp. is likely related to the symbiotic relationship between $C$. vulgaris and ericoid mycorrhizal fungi (Aerts et al., 2009; Bragazza et al., 2010; Emmerton et al., 2001). The transferred $\mathrm{N}$ from mycorrhiza to shrubs appears to be depleted relative to soil N (Gebauer and Dietrich, 1993). Nevertheless, though differences in $\delta^{13} \mathrm{C}$ and $\delta^{15} \mathrm{~N}$ between PFT existed, unknown variables influencing $\delta^{13} \mathrm{C}$ and $\delta^{15} \mathrm{~N}$ in peat, such as various plant species growing in the peat, and $\mathrm{N}$ deposition history complicated the use of $\delta^{13} \mathrm{C}$ and $\delta^{15} \mathrm{~N}$ as vegetation proxies.

By applying PCA to pyrolysates of plant and peat samples, we were able to clearly separate mosses from vascular plants and shrubs from sedges. The pyrolysis product specific for Sphagnum (4-isopropenylphenol) and the sum of ligninderived products indicating vascular plants were particularly 
useful (Fig. 3a, b). Furthermore, the ratio of 4-vinylguaiacol to the summed guaiacyl products $(4 \mathrm{VG} / \mathrm{G})$ indeed could be used to reflect sedges (Fig. 3c, d). Additionally, the ratio of $\mathrm{C}_{3}$-guaiacol to the summed guaiacyl products $\left(\mathrm{C}_{3} \mathrm{G} / \mathrm{G}\right)$ and the sum of $n$-alkenes and $n$-alkanes (Al) could be confirmed as parameters indicative of shrubs (Fig. 3c, d).

\subsubsection{Effects of vascular plants on chemical properties of the moss-dominated peat}

The high contribution of polysaccharides and phenols to peat pyrolysates (Table 3 ) and a strong positive correlation of the marker for sphagnum acid (4-isopropenylphenol) with the summed phenols (adjusted $R^{2}=0.98$; Fig. 5a) indicate that the peat is dominated by Sphagnum tissue. The close positions of both peat samples and living Sphagnum shoots along $\mathrm{PC} 1$ visualize the dominance of Sphagnum in the peat. Furthermore, the similarity of $\mathrm{C} / \mathrm{N}$ ratios, $\delta^{13} \mathrm{C}$ and $\delta^{15} \mathrm{~N}$ of the uppermost peat increment to those of moss are indicative of moss-dominated peat (Schaub and Alewell, 2009) and has been measured likewise in Sphagnum peatlands by Kracht and Gleixner (2000). Thus, Sphagnum tissues dominate the peat of our two sites. Nevertheless, py-GC/MS indicates that the moss-dominated peat has a contribution from vascular plants as lignin-derived products contributed up to $15 \%$ to pyrolysates, particularly in the deeper increments under sedge coverage (Fig. 4a). Peat composition under shrubs and sedges is influenced by these species in the studied peat $(0-20 \mathrm{~cm})$ as indicated by the molecular parameters for sedge and shrub in the corresponding peat cores (Fig. 4b, c, d). The sedge parameter (i.e., the ratio of 4-vinylguaiacol to the sum of guaiacols; Table 1) was higher in sedge core samples than in shrub core samples (Fig. 4b), illustrating a noticeable contribution from sedges to the peat. The correlation between the sedge parameter and the sum of lignin-derived products (adjusted $R^{2}=0.52$, Fig. 5 c) indicates a strong contribution from sedges on lignin in sedge cores. The contribution of shrubs to peat composition, as indicated by the suggested shrub parameter (i.e., the sum of $n$-alkenes and $n$-alkanes; Table 1), seems to be particularly high in the upper three peat increments as this parameter was mostly higher for shrub core samples than for sedge core samples in those increments (Fig. 4d). The increasing $\mathrm{C} / \mathrm{N}$ ratios with depth at both sites could indicate a larger contribution of roots to the mossdominated peat, since roots had much higher $\mathrm{C} / \mathrm{N}$ ratios than shoots and moss (Figs. 1, 2a).

By using py-GC/MS we could show that the peat was dominated by Sphagnum and had a contribution from vascular plants; furthermore, we could validate the selected parameters described in the literature to reflect the contribution from sedge and shrub at the two sites.

\subsection{Decomposition of the moss-dominated peat}

Most of the studied parameters changed with depth in the peat cores and might be indicative of the assumed increase in peat decomposition with depth, i.e., with increasing time of exposure to oxygen after peat formation. In all peat cores, $\delta^{13} \mathrm{C}$ and $\delta^{15} \mathrm{~N}$ increased with depth. Since $\delta^{13} \mathrm{C}$ and $\delta^{15} \mathrm{~N}$ showed a positive correlation (adjusted $R^{2}=0.48$, Fig. $5 \mathrm{~b}$ ), their increases with depth may be caused by the same processes. The preferential uptake of lighter isotopes $\left({ }^{12} \mathrm{C}\right.$, ${ }^{14} \mathrm{~N}$ ) for respiration by aerobic decomposers during decomposition causes a relative enrichment of heavier isotopes $\left({ }^{13} \mathrm{C},{ }^{15} \mathrm{~N}\right.$ ) in the remaining organic matter (Krüger et al., 2014, 2015; Nadelhoffer and Fry, 1988; Schaub and Alewell, 2009), suggesting that ${ }^{13} \mathrm{C}$ and ${ }^{15} \mathrm{~N}$ depth trends are due to decomposition. Because $\delta^{15} \mathrm{~N}$ trends may also be superimposed by $\mathrm{N}$ deposition (Novák et al., 2014) and fractionation processes during $\mathrm{N}$ fixation (Novák et al., 2016), $\delta^{13} \mathrm{C}$ seems to be a better indicator for peat decomposition in our study. Nevertheless, also $\delta^{13} \mathrm{C}$ peat records might be superimposed by differences in $\delta^{13} \mathrm{C}$ between shoots and roots, plant species, or site-specific differences in ${ }^{13} \mathrm{C}$ discrimination (Sect. 4.1.1). Differences in the $\mathrm{C} / \mathrm{N}$ ratios did not provide a consistent picture regarding changes in peat decomposition. We speculate that the observed increasing $\mathrm{C} / \mathrm{N}$ ratio with depth might reflect an increasing $\mathrm{N}$ deposition in the past decades (Galloway et al., 2008) and an increased contribution of roots (high $\mathrm{C} / \mathrm{N}$ ratios, Fig. 1a) to peat formation with increasing depth (Sect. 4.1.2). $\mathrm{N}$ deposition at the high $T$ site was reported to be $8.2 \mathrm{~kg} \mathrm{ha}^{-1} \mathrm{yr}^{-1}$ (Bragazza et al., 2005) and for peatlands in northern Italy between 4.2 and $>10 \mathrm{~kg} \mathrm{ha}^{-1} \mathrm{yr}^{-1}$ (Bragazza et al., 2003, 2005).

In addition to changes in $\delta^{13} \mathrm{C}$ and $\delta^{15} \mathrm{~N}$ reflecting the decomposition of the bulk peat (i.e., cumulative effects on all peat components), we examined changes in compounds being indicative of the decomposition of specific plant tissues, i.e., Sphagnum-derived peat (4-isopropenylphenol). Sphagnum acid and its pyrolysis product 4-isopropenylphenol have been found to very sensitively reflect aerobic decomposition of Sphagnum tissue (Abbott et al., 2013; Schellekens et al., 2015b). The observed decrease in 4-isopropenylphenol with depth occurred in all four peat cores (Fig. 4e), and its negative correlation with $\delta^{13} \mathrm{C}$ (adjusted $R^{2}=0.27$, Fig. 5d) confirms the increase in peat decomposition with depth as indicated by ${ }^{13} \mathrm{C}$.

The detected increase in polysaccharides with depth (Table 3) likely reflects the relative accumulation of rather resistant polysaccharides of Sphagnum cell walls during aerobic decomposition (Hájek et al., 2011) and the preferential decomposition of Sphagnum phenols (Schellekens et al., 2015b). However, the polysaccharide products from the peat samples can have multiple sources, too (e.g., Sphagnum cell walls or lignocellulose from vascular plants; Sarkar et al., 2009). Similarly, the increase with depth of the ratio of levoglucosan to the sum of polysaccharide-derived prod- 

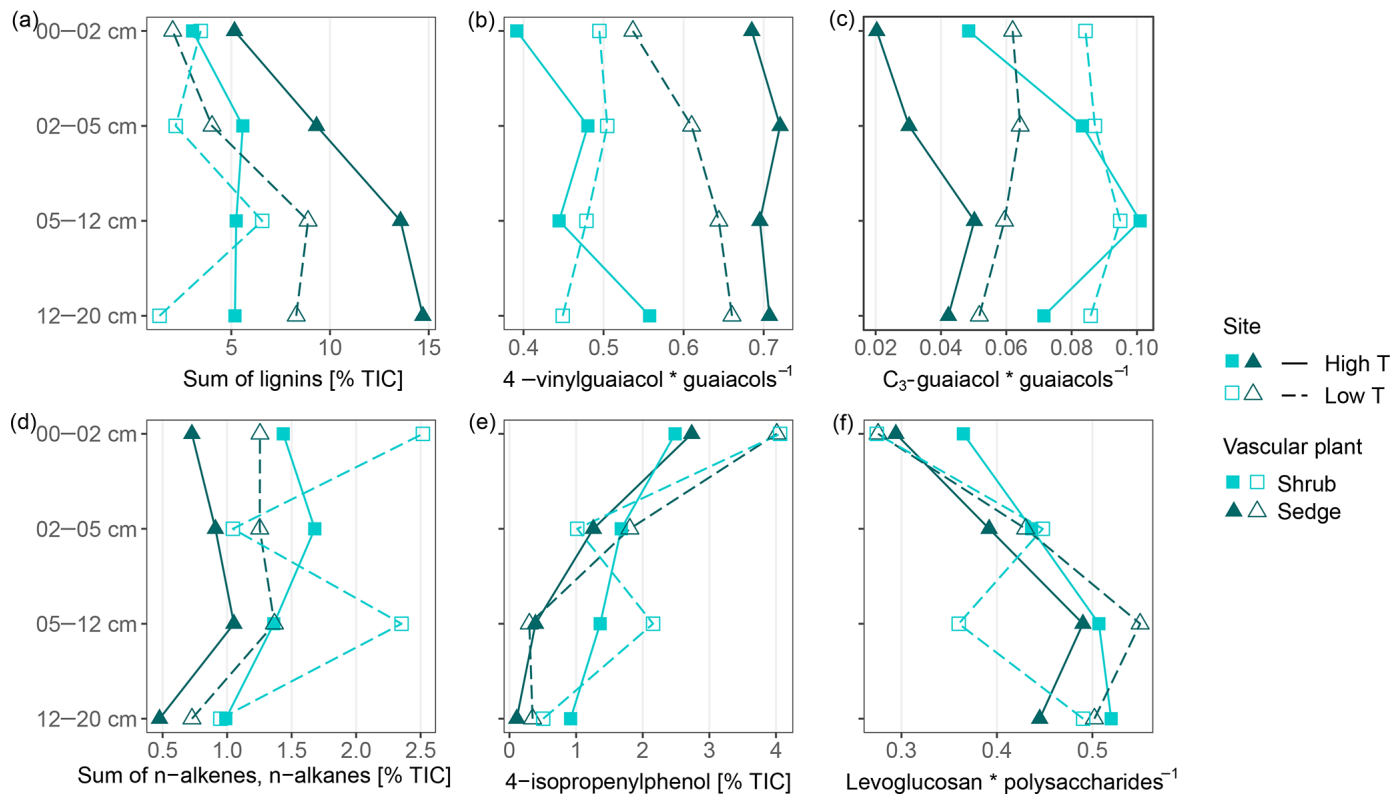

Vascular plant

$\square$ Shrub

$\Delta$ Sedge

Figure 4. Parameters that reflect vascular plant input in moss-dominated peat (a-d) and decomposition of the moss-dominated peat (e, f) in peat core increments from both sites and given peat cores. Data derived from pyrolysis-gas chromatography/mass-spectrometry.
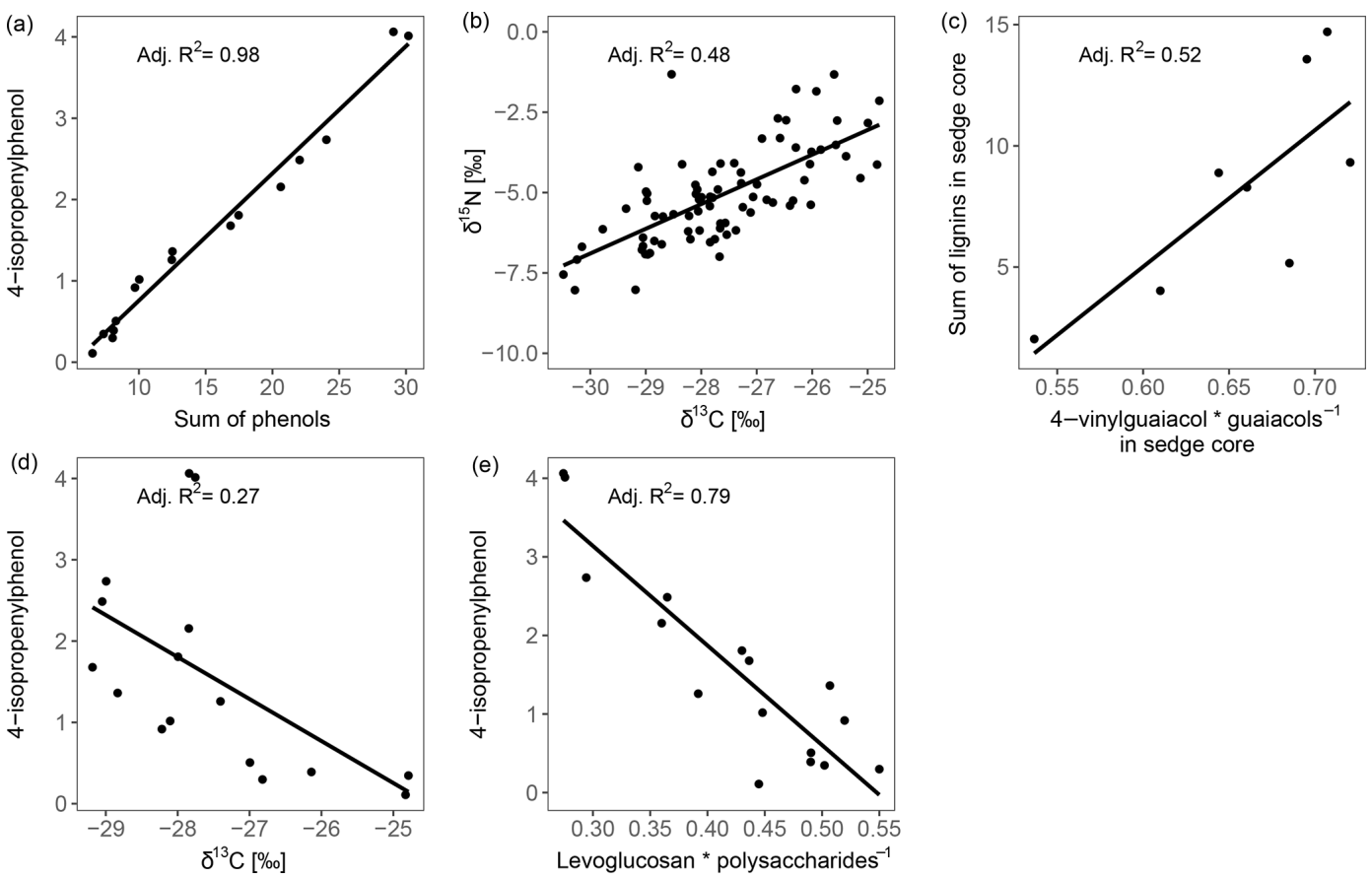

Figure 5. Regression plots between parameters describing decomposition of the moss-dominated peat and the impact of vascular plants on peat properties.

ucts $(\mathrm{L} / \mathrm{Ps})$ may reflect the relative preservation of Sphagnum polysaccharides during aerobic decomposition (Table 1, Fig. 4f). This is confirmed by a strong negative correlation between this ratio and 4-isopropenylphenol (adjusted $R^{2}=0.79$, Fig. 5e) and further by the positive loading of $\mathrm{L} / \mathrm{Ps}$ on $\mathrm{PC} 2$.

\subsubsection{Effects of vascular plants on decomposition of moss-dominated peat}

We found three indicators that decomposition of mossdominated peat with depth is boosted by sedge coverage compared to shrub coverage. Increases in $\delta^{13} \mathrm{C}$ with depth 
were higher for sedge cores than for shrub cores (Fig. 2b), and the decrease with depth of 4-isopropenylphenol was mostly stronger in sedge cores than shrub cores (Fig. 4e). In general, the L/Ps ratio increased with depth (Fig. 4f). This ratio decreased only in the deepest increment of sedge cores. This decrease could indicate that decomposition under sedge coverage in the deepest peat increment is so high that even less decomposable polysaccharides have been decomposed. Because this is not evident from the 4-isopropenylphenol record, it probably reflects a higher contribution of sedgederived polysaccharides at these depths.

The observed decomposition patterns were detected by a parameter describing the whole peat $\left(\delta^{13} \mathrm{C}\right)$ but were also reflected by compounds indicative of Sphagnum material (4isopropenylphenol). The latter suggests that (changes in) vascular plant composition may affect the decomposition of the existing Sphagnum peat by changing plant-soil feedbacks (Bragazza et al., 2013; Gavazov et al., 2018; Robroek et al., 2015). The observed higher degree of degradation of peat under sedges than under shrubs may be explained by differences in litter quality or root traits. Sedge litter is likely to be more readily decomposable compared to shrub litter, which is caused by its lower C/N ratios (Fig. 1a; Huang et al., 1998; Kaštovská et al., 2018; Laiho et al., 2003; Limpens and Berendse, 2003). Furthermore, additional oxygenation by the aerenchyma of $E$. vaginatum might trigger further decomposition of moss-dominated peat (Armstrong, 1964; HolzapfelPschorn et al., 1986; Roura-Carol and Freeman, 1999). This process is particularly relevant at the low $T$ site, where the uppermost $20 \mathrm{~cm}$ of the peat remained water saturated much longer than at the high $T$ site.

\subsubsection{Temperature effects on decomposition of the moss-dominated peat - interactions with vascular plant effects}

The altitudinal gradient has been used to reveal the potential effects of increasing temperature and associated lower water table on peat decomposition by comparing the suggested decomposition parameters (Table 1) between the high $T$ and low $T$ site. Increases in $\delta^{13} \mathrm{C}$ with depth were higher at the high $T$ site than at the low $T$ site (Fig. 2). Therefore, decomposition of the moss-dominated peat is likely to be increased at the high $T$ site compared to the low $T$ site independent of the vascular plant species.

However, depth trends of the Sphagnum-specific decomposition parameter (4-isopropenylphenol) do not reflect this increased peat decomposition at higher temperatures. 4Isopropenylphenol decreased less at the high $T$ site compared to the low $T$ site (Fig. 4e). We might speculate about a difference in temperature sensitivity between decomposition of Sphagnum and the whole peat, but such a hypothesis needs to be tested by, e.g., temperature-controlled incubation experiments.
The ratio of levoglucosan to the sum of polysaccharides (Fig. 4f) did not show consistent trends related to temperature, again indicating no temperature enhanced degradation of the moss-dominated peat. Vascular plants and particularly sedges might increasingly contribute to polysaccharides with higher temperatures (see Sect. 4.2.1). These changes from more Sphagnum-derived polysaccharides to more sedge-derived polysaccharides could change decomposition dynamics of polysaccharides, since cell walls constituents from Sphagnum were found to be less easily decomposable (Hájek et al., 2011). A higher contribution from sedges could therefore superimpose a potential enrichment of Sphagnum-derived polysaccharides with depth. On the other hand, it seems unlikely that the observed depth trends for the Sphagnum-specific 4-isopropenylphenol have been affected in a similar way as the less specific ratio of levoglucosan to the sum of polysaccharides. Given the above, the higher degree of peat decomposition at the high $T$ site picked up by $\delta^{13} \mathrm{C}$ is probably mediated by higher input rates of easily decomposable vascular plant litter, notably sedges, combined with the warmer and drier conditions favoring aerobic decomposition processes (Biester et al., 2014).

This combined effect of sedges and temperature on peat decomposition has implications for the long-term $\mathrm{C}$ storage in Sphagnum-dominated peatlands because of projected shifts from sedges to shrubs with climate change (Breeuwer et al., 2009). That change towards fewer sedges may partly offset temperature-driven decomposition processes because of the observed enhancing effect of sedges on peat decomposition. Fewer sedges (i.e., more shrubs) should result in less peat degradation because (i) the decomposability of available litter (higher contribution of shrub litter) is reduced as its chemical composition indicates less decomposability (Kristensen and McCarty, 1999; Ward et al., 2015), (ii) an increasing presence of shrubs $(C$. vulgaris) suppresses belowground biota activity and nutrient cycling (Fenner and Freeman, 2011), (iii) C. vulgaris associates with mycorrhizal fungi which increase the uptake of organic nutrients leading to an increase in the $\mathrm{C} / \mathrm{N}$ ratio (Read et al., 2004) and thus a decrease in peat decomposition (Ward et al., 2015), (iv) the input of labile $\mathrm{C}$ into peat via sedge roots is lower (Crow and Wieder, 2005; Robroek et al., 2015), and (v) the transport of oxygen into peat via aerenchyma of E. vaginatum is lower. On the other hand, Zeh et al. (2019) could show that shrubs translocated more $\mathrm{C}$ into the peat at higher temperatures than sedges, which could result in a reinforcing effect on peat decomposition with increasing temperature. Obviously, the enhanced $\mathrm{C}$ input by shrubs into peat did not coincide with enhanced decomposition of the moss-dominated peat on these sites. 


\section{Conclusions}

The studied plant functional types differed in the chemical composition of their biomass and therefore in litter quality. Although both peatlands were moss dominated, the application of several complementary parameters revealed clear influences from sedge and shrub litter. Combining data obtained by py-GC/MS and isotopic analysis enabled separating the effects of PFT and temperature on peat decomposition under field conditions. Whereas changes in $\delta^{13} \mathrm{C}$ depth records reflected the state of peat degradation, its application to disentangle the effects of source material, decomposition processes, and environmental factors is incomplete. The $\mathrm{C} / \mathrm{N}$ ratio and $\delta^{15} \mathrm{~N}$ were not specific enough to represent vascular plant effects on decomposition of the moss-dominated peat. Combining records of molecular parameters and $\delta^{13} \mathrm{C}$ indicated that moss-dominated peat was more decomposed under sedge than under shrub coverage, particularly under high temperatures. The most important and also surprising result of our study was that vascular plants had a more pronounced impact on peat decomposition than temperature and associated lower water tables together. Potential $\mathrm{O}_{2}$ transport by the aerenchyma of sedges probably did not contribute to enhanced peat decomposition at the high $T$ site, as the top $20 \mathrm{~cm}$ peat layer sampled remained above the water table, and thus aerated, for most of the year. Considering that climate change can lead to a shift from Sphagnum mosses to vascular plants and from sedges to shrubs (Breeuwer et al., 2009), an increase in sedge coverage may enhance the decomposition of Sphagnum peat in surface layers at elevated temperature. To what extent this increased decomposition may be partly compensated for by the growing dominance of shrubs over sedges with climate change deserves further studies in order to link belowground decomposition to aboveground production. 


\section{Appendix A}

Table A1. Quantified pyrolysis products, their codes, retention time (RT) and specific ion fragments $(\mathrm{m} / \mathrm{z}$ ) used for quantification.

\begin{tabular}{|c|c|c|c|}
\hline Code & Pyrolysis product & $m / z$ & $\mathrm{RT}(\mathrm{min})$ \\
\hline - & $\mathrm{C}_{19}-\mathrm{C}_{28} n$-alkenes & 55,69 & - \\
\hline- & $\mathrm{C}_{19}-\mathrm{C}_{29} n$-alkanes & 57,71 & - \\
\hline $\mathrm{Be} 1$ & benzene & 78 & 2.365 \\
\hline $\mathrm{Be} 2$ & toluene & 91,92 & 3.86 \\
\hline Lg1 & 4-vinylphenol & 91,120 & 20.117 \\
\hline Lg2 & guaiacol & 109,124 & 15.232 \\
\hline Lg3 & 4-methylguaiacol & 123,138 & 19.092 \\
\hline Lg4 & 4-vinylguaiacol & 135,150 & 23.314 \\
\hline Lg5 & $\mathrm{C}_{3}$ guaiacol, trans & 164 & 27.73 \\
\hline Lg6 & 4-acetylguaiacol & 151,166 & 28.9 \\
\hline Lg7 & syringol & 139,154 & 24.621 \\
\hline Lg8 & 4-methylsyringol & 153,168 & 27.687 \\
\hline Lg9 & 4-vinylsyringol & 165,180 & 31.239 \\
\hline $\operatorname{Lg} 10$ & $\mathrm{C}_{3}$ syringol, trans & 194 & 35.049 \\
\hline Lg11 & 4-acetylsyringol & 181,196 & 35.987 \\
\hline $\mathrm{Ph} 1$ & phenol & 66,94 & 11.216 \\
\hline $\mathrm{Ph} 2$ & $\mathrm{C}_{1}$ phenol & 107,108 & 14.031 \\
\hline $\mathrm{Ph} 3$ & $\mathrm{C}_{1}$ phenol & 107,108 & 14.819 \\
\hline $\mathrm{Ph} 4$ & $\mathrm{C}_{2}$ phenol & 107,122 & 18.241 \\
\hline $\mathrm{Ph} 5$ & catechol & 110 & 19.536 \\
\hline $\mathrm{Ph} 6$ & 4-isopropenylphenol & 119,134 & 23.039 \\
\hline $\mathrm{Ph} 7$ & p-hydroxybiphenyl & 170 & 35.33 \\
\hline Ps1 & (2H)furan-3-one & 54,84 & 4.566 \\
\hline Ps2 & 2-furaldehyde & 95,96 & 5.605 \\
\hline Ps3 & 2,3-dihydro-5-methylfuran-2-one & 98 & 8.826 \\
\hline Ps4 & unidentified carbohydrate & 55,86 & 10.29 \\
\hline Ps5 & 5-methyl-2-furaldehyde & 109,110 & 10.328 \\
\hline Ps6 & 4-hydroxy-5,6-dihydro-( $2 H)$-pyran-2-one & 114 & 11.648 \\
\hline Ps7 & 2-hydroxy-3-methyl-2-cyclopenten-1-one & 55,112 & 12.861 \\
\hline Ps8 & dianhydrorhamnose & 113,128 & 13.324 \\
\hline Ps9 & unidentified carbohydrate & 128,72 & 15.057 \\
\hline Ps10 & unidentified carbohydrate & 56,114 & 16.52 \\
\hline Ps11 & 1,4:3,6-dianhydro- $\alpha$-D-glucose & 69,57 & 19.617 \\
\hline Ps12 & 1,4-Anhydroxylofuranose & 57 & 21.644 \\
\hline Ps13 & 1,4-Dideoxy-D-glycero-hex-1-enopyranose-3-ulose & 87,144 & 22.882 \\
\hline Ps14 & levogalactosan & 60 & 25.359 \\
\hline Ps15 & levomannosan & 60 & 27.862 \\
\hline Ps16 & levoglucosan & 60 & 30.045 \\
\hline
\end{tabular}


Data availability. The underlying py-GC/MS data can be accessed via https://doi.org/10.25532/OPARA-77 (Zeh, 2020a). Carbon-tonitrogen $(\mathrm{C} / \mathrm{N})$ ratios, $\delta^{15} \mathrm{~N}(\% \circ)$ and $\delta^{13} \mathrm{C}(\% \circ)$ of shoot and root tissues from the three peat-forming plants and of peat increments are available via https://doi.org/10.25532/OPARA-78 (Zeh, 2020b) and https://doi.org/10.25532/OPARA-79 (Zeh, 2020c), respectively.

Author contributions. JL, LB and KK designed the study and MTI, LZ, JL, LB and KK collected the samples and data in the field. MTI and LZ processed the samples and performed the analyses. JS contributed to the py-GC/MS part of the article, including analysis of the data and editing on the paper. LZ took the lead in preparing the manuscript, with contributions from all coauthors.

Competing interests. The authors declare that they have no conflict of interest.

Acknowledgements. We thank the Ufficio Ecologia del Paesaggio Provincia Autonoma di Bolzano and the Servizio Sviluppo Sostenibile e Aree Protette - Provincia Autonoma di Trento for access to the Italian sites; Manuela Unger and Gisela Ciesielski for sample preparation and analyses of $\mathrm{C}, \mathrm{N}$ and stable isotopes in the laboratory; and Josephine Hillig for carrying out the py-GC/MS measurements.

Financial support. This research has been supported by the TU Dresden, Wageningen University and University of Ferrara (FAR 2014), as well as FAPESP projects 2013/03953-9 and 2016/033374. The py-GC/MS system was funded by DFG project INST 269/575-1. Open Access Funding was provided by the Publication Fund of the TU Dresden.

Review statement. This paper was edited by Sébastien Fontaine and reviewed by Tim Moore and one anonymous referee.

\section{References}

Abbott, G. D., Swain, E. Y., Muhammad, A. B., Allton, K., Belyea, L. R., Laing, C. G., and Cowie, G. L.: Effect of watertable fluctuations on the degradation of Sphagnum phenols in surficial peats, Geochim. Cosmochim. Acta, 106, 177-191, https://doi.org/10.1016/j.gca.2012.12.013, 2013.

Aerts, R., Callaghan, T. V., Dorrepaal, E., Van Logtestijn, R. S. P., and Cornelissen, J. H. C.: Seasonal climate manipulations result in species-specific changes in leaf nutrient levels and isotopic composition in a sub-arctic bog, Funct. Ecol., 23, 680-688, https://doi.org/10.1111/j.1365-2435.2009.01566.x, 2009.

Alewell, C., Giesler, R., Klaminder, J., Leifeld, J., and Rol$\log$, M.: Stable carbon isotopes as indicators for environmental change in palsa peats, Biogeosciences, 8, 1769-1778, https://doi.org/10.5194/bg-8-1769-2011, 2011.
Armstrong, W.: Oxygen diffusion from the roots of some british bog plants, Nature, 204, 801-802, 1964.

Asada, T., Warner, B. G., and Aravena, R.: Nitrogen isotope signature variability in plant species from open peatland, Aquat. Bot., 82, 297-307, https://doi.org/10.1016/j.aquabot.2005.05.005, 2005.

Bates, D., Maechler, M., Bolker, B., and Walker, S.: Fitting Linear Mixed-Effects Models Using lme4, J. Stat. Softw, 67, 1-48. https://doi.org/10.18637/jss.v067.i01, 2015

Berendse, F., Van Breemen, N., Rydin, Ha., Buttler, A., Heijmans, M., Hoosbeek, M. R., Lee, J. A., Mitchell, E., Saarinen, T., Vasander, H., and Wallen, B.: Raised atmospheric $\mathrm{CO}_{2}$ levels and increased $\mathrm{N}$ deposition cause shifts in plant species composition and production in Sphagnum bogs, Glob. Chang. Biol., 7, 591598, https://doi.org/10.1046/j.1365-2486.2001.00433.x, 2001.

Biester, H., Knorr, K.-H., Schellekens, J., Basler, A., and Hermanns, Y.-M.: Comparison of different methods to determine the degree of peat decomposition in peat bogs, Biogeosciences, 11, 26912707, https://doi.org/10.5194/bg-11-2691-2014, 2014.

Bragazza, L., Gerdol, R., and Rydin, H.: Effects of mineral and nutrient input on mire bio-geochemistry in two geographical regions, J. Ecol., 91, 417-426, https://doi.org/10.1046/j.13652745.2003.00773.x, 2003.

Bragazza, L., Limpens, J., Gerdol, R., Grosvernier, P., Hájek, M., Hájek, T., Hajkova, P., Hansen, I., Iacumin, P., Kutnar, L., Rydin, H., and Tahvanainen, T.: Nitrogen concentration and $\delta 15 \mathrm{~N}$ signature of ombrotrophic Sphagnum mosses at different $\mathrm{N}$ deposition levels in Europe, Glob. Chang. Biol., 11, 106-114, https://doi.org/10.1111/j.1365-2486.2004.00886.x, 2005.

Bragazza, L.: A decade of plant species changes on a mire in the Italian Alps: Vegetation-controlled or climatedriven mechanisms?, Clim. Change, 77, 415-429, https://doi.org/10.1007/s10584-005-9034-x, 2006.

Bragazza, L. and Iacumin, P.: Seasonal variation in carbon isotopic composition of bog plant litter during 3 years of field decomposition, Biol. Fertil. Soils, 46, 73-77, https://doi.org/10.1007/s00374-009-0406-7, 2009.

Bragazza, L., Iacumin, P., Siffi, C., and Gerdol, R.: Seasonal variation in nitrogen isotopic composition of bog plant litter during 3 years of field decomposition, Biol. Fertil. Soils, 46, 877-881, https://doi.org/10.1007/s00374-010-0483-7, 2010.

Bragazza, L., Parisod, J., Buttler, A., and Bardgett, R. D.: Biogeochemical plant-soil microbe feedback in response to climate warming in peatlands, Nat. Clim. Chang., 3, 273-277, https://doi.org/10.1038/nclimate1781, 2013.

Bragazza, L., Bardgett, R. D., Mitchell, E. A., and Buttler, A.: Linking soil microbial communities to vascular plant abundance along a climate gradient, New Phytol., 205, 1175-1182, https://doi.org/10.1111/nph.13116, 2015.

Breeuwer, A., Robroek, B. J. M., Limpens, J., Heijmans, M. M. P. D., Schouten, M. G. C., and Berendse, F.: Decreased summer water table depth affects peatland vegetation, Basic Appl. Ecol., 10, 330-339, https://doi.org/10.1016/j.baae.2008.05.005, 2009.

Broder, T., Blodau, C., Biester, H., and Knorr, K. H.: Peat decomposition records in three pristine ombrotrophic bogs in southern Patagonia, Biogeosciences, 9, 1479-1491, https://doi.org/10.5194/bg-9-1479-2012, 2012.

Coolen, M. J. L. and Orsi, W. D.: The transcriptional response of microbial communities in thawing 
Alaskan permafrost soils, Front. Microbiol., 6, 1-14, https://doi.org/10.3389/fmicb.2015.00197, 2015.

Coulson, J. C. and Butterfield, J.: An Investigation of the Biotic Factors Determining the Rates of Plant Decomposition on Blanket Bog, J. Ecol., 66, 631-650, 1978.

Crow, S. E. and Wieder, R. K.: Sources of $\mathrm{CO}_{2}$ emission from a northern peatland: Root respiration, exudation, and decomposition, Ecology, 86, 1825-1834, https://doi.org/10.1890/04-1575, 2005.

Damman, A. W. H.: Regulation of Nitrogen Removal and Retention in Sphagnum bogs and Other Peatlands, Oikos, 51, 291, https://doi.org/10.2307/3565310, 1988.

Eglinton, G. and Hamilton, R. J.: Leaf Epicuticular Waxes, Science, 156, 1322-1335, https://doi.org/10.1126/science.156.3780.1322, 1967.

Emmerton, K. S., Callaghan, T. V, Jones, H. E., Leake, J. R., Michelsen, A., and Read, D. J.: Assimilation and isotopic fractionation of nitrogen by mycorrhizal and nonmycorrhizal subarctic plants, New Phytol., 151, 513-524, https://doi.org/10.1046/j.1469-8137.2001.00179.x, 2001.

Fenner, N. and Freeman, C.: Drought-induced carbon loss in peatlands, Nat. Geosci., 4, 895-900, https://doi.org/10.1038/ngeo1323, 2011.

Galloway, J. N., Townsend, A. R., Erisman, J. W., Bekunda, M., Cai, Z., Freney, J. R., Martinelli, L. A., Seitzinger, S. P., and Sutton, M. A.: Transformation of the Nitrogen Cycle: Recent Trends, Questions, and Potential Solutions, Science, 320, 889892, https://doi.org/10.1126/science.1136674, 2008.

Gavazov, K., Hagedorn, F., Buttler, A., Siegwolf, R., and Bragazza, L.: Environmental drivers of carbon and nitrogen isotopic signatures in peatland vascular plants along an altitude gradient, Oecologia, 180, 257-264, https://doi.org/10.1007/s00442-0153458-4, 2016.

Gavazov, K., Albrecht, R. J. H., Buttler, A., Dorrepaal, E., Garnett, M. H., Gogo, S., Hagedorn, F., Mills, R. T. E., Robroek, B. J. M., and Bragazza, L.: Vascular plant-mediated controls on atmospheric carbon assimilation and peat carbon decomposition under climate change, Glob. Chang. Biol., 24, https://doi.org/10.1111/gcb.14140, 2018.

Gebauer, G. and Dietrich, P.: Nitrogen Isotope Ratios in Different Compartments of a Mixed Stand of Spruce, Larch and Beech Trees and of Understorey Vegetation Including Fungi, Isot. Isot. Environ. Heal. Stud., 29, 35-44, https://doi.org/10.1080/10256019308046133, 1993.

Gerdol, R., Siffi, C., and Bombonato, L.: Aboveground production and nutrient status of the vegetation of different mire types in the South-eastern Alps (Italy), Bot. Helv., 120, 85-93, https://doi.org/10.1007/s00035-010-0077-x, 2010.

Hájek, T., Ballance, S., Limpens, J., Zijlstra, M., and Verhoeven, J. T. A.: Cell-wall polysaccharides play an important role in decay resistance of Sphagnum and actively depressed decomposition in vitro, Biogeochemistry, 103, 45-57, https://doi.org/10.1007/s10533-010-9444-3, 2011.

Heijmans, M. M. P. D., Mauquoy, D., van Geel, B., and Berendse, F.: Long-term effects of climate change on vegetation and carbon dynamics in peat bogs, J. Veg. Sci., 19, 307-320, https://doi.org/10.3170/2008-8-18368, 2008.
Holzapfel-Pschorn, A., Conrad, R., and Seiler, W.: Effects of vegetation on the emission of methane from submerged paddy soil, Plant Soil, 92, 223-233, 1986.

Hornibrook, E. R. C., Longstaffe, F. J., Fyfe, W. S., and Bloom, Y.: Carbon-isotope ratios and carbon, nitrogen and sulfur abundances in flora and soil organic matter from a temperate-zone bog and marsh, Geochem. J., 34, 237-245, https://doi.org/10.2343/geochemj.34.237, 2000.

Huang, Y., Stankiewicz, B. A., Eglinton, G., Snape, C. E., Evans, B., Latter, P. M., and Ineson, P.: monitoring Biomacromolecular degradation of Calluna Vulgaris in a 23year field experiment using solid state ${ }^{13} \mathrm{C}-\mathrm{NMR}$ and pyrolysis-GC/MS, Soil Biol. Biochem., 30, 1517-1528, https://doi.org/10.1016/S00380717(97)00234-4, 1998.

Kalbitz, K., Geyer, S., and Gehre, M.: Land use impacts on the isotopic signature $\left({ }^{13} \mathrm{C},{ }^{14} \mathrm{C},{ }^{15} \mathrm{~N}\right)$ of water-soluble fulvic acids in a German fen area, Soil Sci., 165, 728-736, https://doi.org/10.1097/00010694-200009000-00006, 2000.

Karhu, K., Auffret, M. D., Dungait, J. a J., Hopkins, D. W., Prosser, J. I., Singh, B. K., Subke, J. A., Wookey, P. a, Agren, G. I., Sebastià, M.-T., Gouriveau, F., Bergkvist, G., Meir, P., Nottingham, A. T., Salinas, N., and Hartley, I. P.: Temperature sensitivity of soil respiration rates enhanced by microbial community response., Nature, 513, 81-84, https://doi.org/10.1038/nature13604, 2014.

Kaštovská, E., Straková, P., Edwards, K., Urbanová, Z., Bárta, J., Mastný, J., Šantrůčková, H., and Picek, T.: Cotton-Grass and Blueberry have Opposite Effect on Peat Characteristics and Nutrient Transformation in Peatland, Ecosystems, 21, 443-458, https://doi.org/10.1007/s10021-017-0159-3, 2018.

Kohzu, A., Matsui, K., Yamada, T., Sugimoto, A., and Fujita, N.: Significance of rooting depth in mire plants: Evidence from natural $15 \mathrm{~N}$ abundance, Ecol. Res., 18, 257-266, https://doi.org/10.1046/j.1440-1703.2003.00552.x, 2003.

Kracht, O. and Gleixner, G.: Isotope analysis of pyrolysis products from Sphagnum peat and dissolved organic matter from bog water, Org. Geochem., 31, 645-654, https://doi.org/10.1016/S01466380(00)00041-3, 2000.

Kristensen, H. L. and McCarty, G. W.: Mineralization and immobilization of nitrogen in heath soil under intact Calluna, after heather beetle infestation and nitrogen fertilization, Appl. Soil Ecol., 13, 187-198, https://doi.org/10.1016/S09291393(99)00036-0, 1999.

Krüger, J. P., Leifeld, J., and Alewell, C.: Degradation changes stable carbon isotope depth profiles in palsa peatlands, Biogeosciences, 11, 3369-3380, https://doi.org/10.5194/bg-11-33692014, 2014.

Krüger, J. P., Leifeld, J., Glatzel, S., Szidat, S., and Alewell, C.: Biogeochemical indicators of peatland degradation - a case study of a temperate bog in northern Germany, Biogeosciences, 12, 28612871, https://doi.org/10.5194/bg-12-2861-2015, 2015.

Kuhry, P. and Vitt, D. H.: Fossil Carbon/Nitrogen Ratios as a Measure of Peat Decomposition, Ecology, 77, 271-275, https://doi.org/10.2307/2265676, 1996.

Kuznetsova, A., Brockhoff, P. B., and Christensen, R. H. B.: lmerTest Package: Tests in Linear Mixed Effects Models, J. Stat. Softw., 82, 1-26. https://doi.org/10.18637/jss.v082.113, 2017

Laiho, R., Vasander, H., Penttilä, T., and Laine, J.: Dynamics of plant-mediated organic matter and nutrient cycling following 
water-level drawdown in boreal peatlands, Global Biogeochem. Cycles, 17, 22/1-22/11, https://doi.org/10.1029/2002GB002015, 2003.

Lenth, R.: emmeans: Estimated Marginal Means, aka LeastSquares Means. R package version 1.3.4., available at: https: //CRAN.R-project.org/package=emmeans, last access: 19 December 2019.

Limpens, J. and Berendse, F.: How litter quality affects mass loss and $\mathrm{N}$ loss from decomposing Sphagnum, Oikos, 103, 537-547, https://doi.org/10.1034/j.1600-0706.2003.12707.x, 2003.

Lu, F. and Ralph, J.: Detection and Determination of $\mathrm{p}$ Coumaroylated Units in Lignins, J. Agric. Food Chem., 47, 1988-1992, https://doi.org/10.1021/jf981140j, 1999.

Malmer, N., Svensson, B. M., and Wallén, B.: Interactions between Sphagnum mosses and field layer vascular plants in the development of peat-forming systems, Folia Geobot. Phytotaxon., 29, 483-496, https://doi.org/10.1007/BF02883146, 1994.

McClymont, E. L., Bingham, E. M., Nott, C. J., Chambers, F. M., Pancost, R. D., and Evershed, R. P.: Pyrolysis GC-MS as a rapid screening tool for determination of peat-forming plant composition in cores from ombrotrophic peat, Org. Geochem., 42, 14201435, https://doi.org/10.1016/j.orggeochem.2011.07.004, 2011.

Ménot, G. and Burns, S. J.: Carbon isotopes in ombrogenic peat bog plants as climatic indicators: Calibration from an altitudinal transect in Switzerland, Org. Geochem., 32, 233-245, https://doi.org/10.1016/S0146-6380(00)00170-4, 2001.

Nadelhoffer, K. J. and Fry, B.: Controls on natural nitrogen-15 and carbon-13 abundances in forest soil organic matter, Soil Sci. Am. J., 52, 1633-1640, https://doi.org/10.2136/sssaj1988.03615995005200060024x, 1988.

Nierop, K. G. J.: Origin of aliphatic compounds in a forest soil, Org. Geochem., 29, 1009-1016, https://doi.org/10.1016/S01466380(98)00165-X, 1998.

Nordbakken, J. F., Ohlson, M., and Högberg, P.: Boreal bog plants: nitrogen sources and uptake of recently deposited nitrogen, Environ. Pollut., 126, 191-200, https://doi.org/10.1016/S02697491(03)00194-5, 2003

Novák, M., Buzek, F., and Adamová, M.: Vertical trends in $\delta^{13} \mathrm{C}, \delta^{15} \mathrm{~N}$ and $\delta^{34} \mathrm{~S}$ ratios in bulk Sphagnum peat, Soil Biol. Biochem., 31, 1343-1346, https://doi.org/10.1016/S00380717(99)00040-1, 1999.

Novák, M., Stepanova, M., Jackova, I., Vile, M. A., Wieder, R. K., Buzek, F., Adamova, M., Erbanova, L., Fottova, D., and Komarek, A.: Isotopic evidence for nitrogen mobility in peat bogs, Geochim. Cosmochim. Acta, 133, 351-361, https://doi.org/10.1016/j.gca.2014.02.021, 2014.

Novák, M., Jackova, I., Curik, J., Stepanova, M., Veselovsky, F., Buzek, F., Vile, M. A., Bufkova, I., Valkova, I., Adamova, M., Bohdalkova, L., and Komarek, A.: Contrasting $\delta^{15} \mathrm{~N}$ Values of Atmospheric Deposition and Sphagnum Peat Bogs: N Fixation as a Possible Cause, Ecosystems, 19, 1037-1050, https://doi.org/10.1007/s10021-016-9985-y, 2016.

Parish, F., Sirin, A., Charman, D., Joosten, H., Minayeva, T., Silvius, M., and Stringer, L., Eds.: Assessment on Peatlands, Biodiversity and Climate change: Main Report, Global Environment Centre, Kuala Lumpur and Wetlands International, Wageningen, 2008.
Preis, Y. I., Simonova, G. V, Voropay, N. N., and Dyukarev, E. A.: Estimation of the influence of hydrothermal conditions on the carbon isotope composition in Sphagnum mosses of bogs of Western Siberia, IOP Conf. Ser. Earth Environ. Sci., 211, 012031, https://doi.org/10.1088/1755-1315/211/1/012031, 2018.

Price, G. D., McKenzie, J. E., Pilcher, J. R., and Hoper, S. T.: Carbon-isotope variation in Sphagnum from hummock-hollow complexes: Implications for Holocene climate reconstruction, Holocene, 7, 229-233, https://doi.org/10.1177/095968369700700211, 1997.

Proctor, M. C. F., Raven, J. A., and Rice, S. K.: Stable carbon isotope discrimination measurements in Sphagnum and other bryophytes: physiological and ecological implications, J. Bryol., 17, 193-202, https://doi.org/10.1179/jbr.1992.17.2.193, 1992.

R Core Team.: R: A language and environment for statistical computing. R Foundation for Statistical Computing, Vienna, Austria, available at: https://www.R-project.org/, last access: 19 December 2019 .

Read, D. J., Leake, J. R. and Perez-Moreno, J.: Mycorrhizal fungi as drivers of ecosystem processes in heathland and boreal forest biomes, Can. J. Bot., 82, 1243-1263, https://doi.org/10.1139/B04-123, 2004.

Robroek, B. J. M., Albrecht, R. J. H., Hamard, S., Pulgarin, A., Bragazza, L., Buttler, A., and Jassey, V. E. J.: Peatland vascular plant functional types affect dissolved organic matter chemistry, Plant Soil, 103, https://doi.org/10.1007/s11104-015-27103, 2015

Roura-Carol, M. and Freeman, C.: Methane release from peat soils: Effects of Sphagnum and Juncus, Soil Biol. Biochem., 31, 323325, https://doi.org/10.1016/S0038-0717(98)00125-4, 1999.

Sarkar, P., Bosneaga, E., and Auer, M.: Plant cell walls throughout evolution: towards a molecular understanding of their design principles, J. Exp. Bot., 60, 3615-3635, https://doi.org/10.1093/jxb/erp245, 2009.

Schaub, M. and Alewell, C.: Stable carbon isotopes as an indicator for soil degradation in an alpine environment (Urseren Valley, Switzerland), Rapid Commun. Mass Spectrom., 23, 1499-1507, https://doi.org/10.1002/rcm.4030, 2009.

Schellekens, J. and Buurman, P.: N-Alkane distributions as palaeoclimatic proxies in ombrotrophic peat: The role of decomposition and dominant vegetation, Geoderma, 164, 112-121, https://doi.org/10.1016/j.geoderma.2011.05.012, 2011.

Schellekens, J., Buurman, P., and Pontevedra-Pombal, X.: Selecting parameters for the environmental interpretation of peat molecular chemistry - A pyrolysis-GC/MS study, Org. Geochem., 40, 678691, https://doi.org/10.1016/j.orggeochem.2009.03.006, 2009.

Schellekens, J., Buurman, P., Fraga, I., and Martínez-Cortizas, A.: Holocene vegetation and hydrologic changes inferred from molecular vegetation markers in peat, Penido Vello (Galicia, Spain), Palaeogeogr. Palaeoclimatol. Palaeoecol., 299, 56-69, https://doi.org/10.1016/j.palaeo.2010.10.034, 2011.

Schellekens, J., Buurman, P., and Kuyper, T. W.: Source and transformations of lignin in Carexdominated peat, Soil Biol. Biochem., 53, 32-42, https://doi.org/10.1016/j.soilbio.2012.04.030, 2012.

Schellekens, J., Buurman, P., Kuyper, T. W., Abbott, G. D., Pontevedra-Pombal, X., and Martínez-Cortizas, A.: Influence of source vegetation and redox conditions on lignin-based decomposition proxies in graminoid-dominated ombrotrophic 
peat (Penido Vello, NW Spain), Geoderma, 237-238, 270-282, https://doi.org/10.1016/j.geoderma.2014.09.012, 2015a.

Schellekens, J., Bindler, R., Martínez-Cortizas, A., McClymont, E. L., Abbott, G. D., Biester, H., Pontevedra-Pombal, X., and Buurman, P.: Preferential degradation of polyphenols from Sphagnum - 4-Isopropenylphenol as a proxy for past hydrological conditions in Sphagnum-dominated peat, Geochim. Cosmochim. Acta, 150, 74-89, https://doi.org/10.1016/j.gca.2014.12.003, 2015b.

Schellekens, J., Bradley, J. a., Kuyper, T. W., Fraga, I., PontevedraPombal, X., Vidal-Torrado, P., Abbott, G. D., and Buurman, P.: The use of plant-specific pyrolysis products as biomarkers in peat deposits, Quat. Sci. Rev., 123, 254-264, https://doi.org/10.1016/j.quascirev.2015.06.028, 2015c.

Schellekens, J., Buurman, P., Kalbitz, K., Zomeren, A. Van, Vidal-Torrado, P., Cerli, C., and Comans, R. N. J.: Molecular Features of Humic Acids and Fulvic Acids from Contrasting Environments, Environ. Sci. Technol., 51, 1330-1339, https://doi.org/10.1021/acs.est.6b03925, 2017.

Schmidt, M. W. I., Torn, M. S., Abiven, S., Dittmar, T., Guggenberger, G., Janssens, I. A., Kleber, M., Kögel-Knabner, I., Lehmann, J., Manning, D. A. C., Nannipieri, P., Rasse, D. P., Weiner, S., and Trumbore, S. E.: Persistence of soil organic matter as an ecosystem property, Nature, 478, 49-56, https://doi.org/10.1038/nature10386, 2011.

Skrzypek, G., Kałużny, A., Wojtuń, B., and Jędrysek, M.-O.: The carbon stable isotopic composition of mosses: a record of temperature variation, Org. Geochem., 38, 1770-1781, https://doi.org/10.1016/j.orggeochem.2007.05.002, 2007.

Taylor, B. R., Parkinson, D., and Parsons, W. F. J.: Nitrogen and lignin content as predictors of litter decay rates: a microcosm test, Ecology, 70, 97-104, https://doi.org/10.2307/1938416, 1989.

Tegelaar, E. W., Hollman, G., Van Der Vegt, P., De Leeuw, J. W., and Holloway, P. J.: Chemical characterization of the periderm tissue of some angiosperm species: recognition of an insoluble, non-hydrolyzable, aliphatic biomacromolecule (Suberan), Org. Geochem., 23, 239-251, https://doi.org/10.1016/01466380(94)00123-I, 1995.

Turetsky, M. R., Crow, S. E., Evans, R. J., Vitt, D. H., and Wieder, R. K.: Trade-offs in resource allocation among moss species control decomposition in boreal peatlands, J. Ecol., 96, 1297-1305, https://doi.org/10.1111/j.1365-2745.2008.01438.x, 2008.

Van Der Hage, E. R. E., Mulder, M. M., and Boon, J. J.: Structural characterization of lignin polymers by temperature-resolved insource pyrolysis-mass spectrometry and Curie-point pyrolysisgas chromatography/mass spectrometry, J. Anal. Appl. Pyrolysis, 25, 149-183, https://doi.org/10.1016/0165-2370(93)800382, 1993.
Van Der Heijden, E., Boon, J. J., Rasmussen, S. and Rudolph, H.: Sphagnum acid and its decarboxylation product isopropenylphenol as biomarkers for fossilised Sphagnum in peats, Anc. Biomol., 1, 93-107, 1997.

Van Smeerdijk, D. G. and Boon, J. J.: Characterisation of subfossil Sphagnum leaves, rootlets of ericaceae and their peat by pyrolysis-high-resolution gas chromatographymass spectrometry, J. Anal. Appl. Pyrolysis, 11, 377-402, https://doi.org/10.1016/0165-2370(87)85043-X, 1987.

Verhoeven, J. T. A. and Toth, E.: Decomposition of Carex and Sphagnum litter in fens: Effect of litter quality and inhibition by living tissue homogenates, Soil Biol. Biochem., 27, 271-275, https://doi.org/10.1016/0038-0717(94)00183-2, 1995.

Ward, S. E., Ostle, N. J., Oakley, S., Quirk, H., Henrys, P. A., and Bardgett, R. D.: Warming effects on greenhouse gas fluxes in peatlands are modulated by vegetation composition, Ecol. Lett., 16, 1285-1293, https://doi.org/10.1111/ele.12167, 2013.

Ward, S. E., Orwin, K. H., Ostle, N. J., Briones, M. J. I., Thomson, B. C., Griffiths, R. I., Oakley, S., Quirk, H., and Bardgett, R. D.: Vegetation exerts a greater control on litter decomposition than climate warming in peatlands, Ecology, 96, 113-123, https://doi.org/10.1890/14-0292.1, 2015.

Zeh, L.: Pyrolysis data to reveal molecular composition of peat and peat forming plants, TU Dresden, https://doi.org/10.25532/OPARA-77, 2020a.

Zeh, L.: Carbon to nitrogen $(\mathrm{C} / \mathrm{N})$ ratios, $\delta^{15} \mathrm{~N}[\% o]$ and $\delta^{13} \mathrm{C}[\% o]$ of shoot and root tissues from three peat forming plants, TU Dresden, https://doi.org/10.25532/OPARA-78, 2020b.

Zeh, L.: Carbon to nitrogen $(\mathrm{C} / \mathrm{N})$ ratios, $\delta^{15} \mathrm{~N} \quad[\%$ o and $\delta^{13} \mathrm{C}[\% \circ]$ of peat core increments, TU Dresden, https://doi.org/10.25532/OPARA-79, 2020c.

Zeh, L., Limpens, J., Erhagen, B., Bragazza, L., and Kalbitz, K.: Plant functional types and temperature control carbon input via roots in peatland soils, Plant Soil, 438, 19-38, https://doi.org/10.1007/s11104-019-03958-6, 2019.

Zhang, X., Wang, X., Finnegan, P. M., Tan, W., and Mao, R.: Effects of litter mixtures on aerobic decomposition rate and its temperature sensitivity in a boreal peatland, Geoderma, 354, 113890, https://doi.org/10.1016/j.geoderma.2019.113890, 2019. 